\title{
Validation of the SEPHIS Program for the Modeling of the HM Process
}

Edward A. Kyser

Oct 1998

\section{Westinghouse Savannah River Company Savannah River Site Aiken, SC 29808}

Prepared for the U. S. Department of Energy under contract DE-AC09-96SR18500. 


\section{DISCLAIMER}

This report was prepared as an account of work sponsored by an agency of the United States Government. Neither the United States Government nor any agency thereof, nor any of their employees, makes any warranty, express or implied, or assumes any legal liability or responsibility for the accuracy, completeness, or usefulness of any information, apparatus, product, or process disclosed, or represents that its use would not infringe privately owned rights. Reference herein to any specific commercial product, process, or service by trade name, trademark, manufacturer, or otherwise does not necessarily constitute or imply its endorsement, recommendation, or favoring by the United States Government or any agency thereof. The views and opinions of authors expressed herein do not necessarily state or reflect those of the United States Government or any agency thereof.

This report has been reproduced directly from the best available copy.

Available to DOE and DOE contractors from the Office of Scientific and Technical Information, P.O. Box 62, Oak Ridge, TN 37831; prices available from (615) 576-8401.

Available to the public from the National Technical Information Service, U.S. Department of Commerce, 5285 Port Royal Road, Springfield, VA 22161. 


\section{DISCLAIMER}

Portions of this document may be illegible in electronic image products. Images are produced from the best available original document. 


\title{
Validation of the SEPHIS Program for the Modeling of the HM Process
}

\author{
Edward A. Kyser
}

Oct 9, 1998

Technical Reviewers

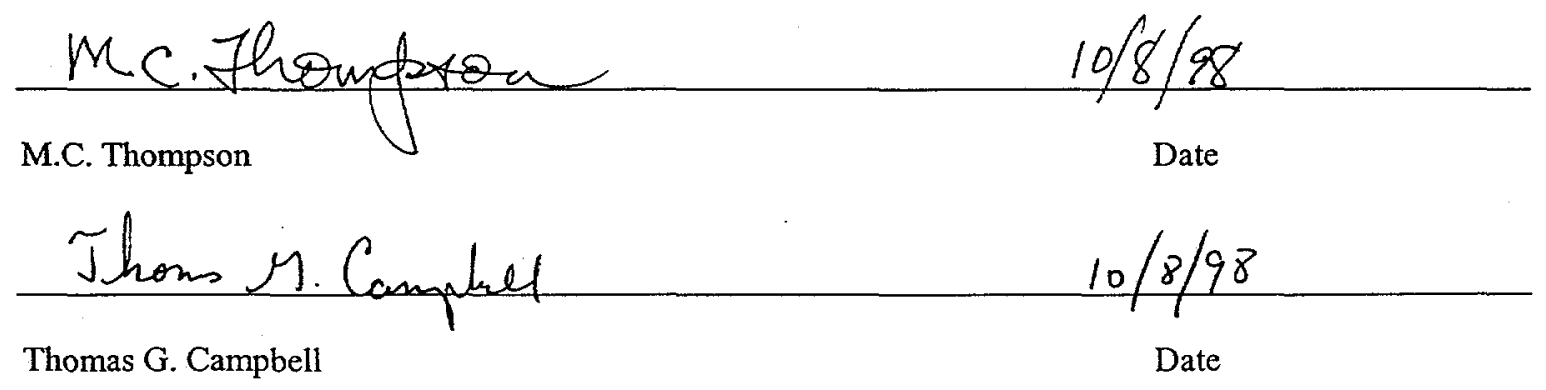



Table of Contents:

Table of Contents $\quad$ iii

List of Figures

List of Tables

Acronyms and Definitions $\quad$ iv

Summary $\quad 5$

Background 6

Historical HM Process in H-Canyon $\quad$. 6

Process Modeling $\quad 8$

Distribution Data $\quad 8$

Calculation Methodology 9

Results and Discussion $\quad 10$

SEPHIS Prediction with Aluminum Nitrate Present 10

Material Balance Check 10

$\mathrm{D}_{\text {ora }}$ Prediction 11

SEPHIS Prediction with Nitric Acid Salting Only 12

Application of SEPHIS to Analyze for Potential Uranium Reflux Conditions 15

Uncertainies $\quad 16$

References $\quad 18$

Appendix $\quad:-20$

\section{List of Figures:}

Figure 1. Current Flowsheet for HM 1st Uranium Cycle Process. $\quad 6$

Figure 2. SEPHIS Predictions as a Function of $U_{\mathrm{a}}$ for DP-1500 Aluminum Nitrate System. 11

Figure 3. SEPHIS Predictions of U Do/a for DP-1384 $\mathrm{HNO}_{3}$ Systems $23^{\circ} \mathrm{C}$. 12

Figure 4. SEPHIS Predictions of $\mathrm{U} \mathrm{D}_{\mathrm{o} / \mathrm{a}}$ for DP- $1384 \mathrm{HNO}_{3}$ Systems $45^{\circ} \mathrm{C}$. 13

Figure 5. SEPHIS Predictions of $\mathrm{U} \mathrm{D}_{\mathrm{o} / \mathrm{a}}$ for DP- $1384 \mathrm{HNO}_{3}$ Systems $60^{\circ} \mathrm{C}$. 13

Figure 6. SEPHIS Error as a Function of $U_{\mathrm{a}}$ Concentration.

Figure 7. SEPHIS Error as a Function of Volume Percent TBP.

Figure 8. SEPHIS Error as a Function of Temperature. $\quad 15$

Figure 9. SEPHIS Error as a Function of $\mathrm{HNO}_{3}$ Concentration. 16

Figure 10. Comparison of SEPHIS Temperature Coefficient for U $D_{\text {ora }}$ with DP-53 Table VIII Data.

List of Tables:

Table I. Operating Conditions, Limits and Assumptions for Modeling the HM 1st Uranium Cycle Process.

Table II. Method for Calculation of $\mathrm{D}_{\mathrm{o} / \mathrm{a}}$ Using SEPHIS.

Table III. SEPHIS versus SASSE Material Balance Comparison.

Table IV. Uranium Distribution Data from DP-53 Table VIII and Comparison with SEPHIS Results.

Table V. Uranium Distribution Data from DP- 1384 Tables $1 \& 4$ for $23^{\circ} \mathrm{C}$ and Comparison with SEPHIS Results.

Table VI. Uranium Distribution Data from DP-1384 Tables $2 \& 5$ for $45^{\circ} \mathrm{C}$ and Comparison with SEPHIS Results.

Table VII. Uranium Distribution Data from DP-1384 Table 3 for $60^{\circ} \mathrm{C}$ and Comparison with SEPHIS Results. 


\section{Acronyms and Definitions:}

ANN, Al - Aluminum nitrate nonahydrate, source of aluminum used to complex fluoride. Aluminum is also present as cladding on SRS reactor fuel and targets.

$D_{o / a}$ - Distribution Coefficient, ratio of concentration in organic phase divided by concentration in aqueous phase

DBP - DiButyl Phosphate, Degradation production from TriButyl Phosphate resulting from the loss of a butyl group and replacement by an acid group. Forms a sodium salt in sodium carbonate solution and is stripped from the solvent.

FS - Ferrous Sulfamate is the primary reducing agent used to adjust $\mathrm{Pu}$ and $\mathrm{Np}$ valence states in the Purex process.

GTM - Generalized Truex Model, Argonne National Laboratory developed software and models used to develop solvent extraction flowsheets. SASSE was a calculational component developed to aid design of such processes.

HLW - High Level Waste, liquid waste containing actinides that will be transferred to the tank farm

SASSE - Excel spreadsheet based macros developed by Argonne National Laboratory for the solution of material balances of countercurrent solvent extraction processes.

SEPHIS - Fortran computer code developed by Oak Ridge National Laboratory in 1975-9 for the solution of material balances of countercurrent solvent extraction processes. This code includes algorithms for the prediction of distribution coefficients for $\mathrm{Pu}$ and $\mathrm{U}$ based on TBP concentration, extractable and inextractable nitrate concentrations and $\mathrm{Pu}$ and $\mathrm{U}$ metal ion concentrations.

SOLVEX - Fortran computer code developed by SRS in 1975 for the solution of material balances of countercurrent solvent extraction process.

Strip - The removal of an extracted component (i.e. Pu) via contact with weak acid, reducing agent or complexant

TBP - TriButyl Phosphate is the extractant used in the Purex solvent extraction process. SRS uses a mixture of straight chain hydrocarbons called normal paraffin hydrocarbon (NPH) with an average carbon chain length of 12 to 14 as a diluent for its TBP processes.

TRUEX - TRansUranium EXtraction, General description given to various processes proposed for the separation of many component waste streams containing actinides via countercurrent flow solvent extraction.

$\mathrm{Ua}$ - Aqueous concentration of $U(\mathrm{~g} / \mathrm{l})$, assumed to be pure $U 235$ for purposes of conversion between molar units and $\mathrm{g} / \mathrm{l}$ units.

Uo - Organic concentration of $U(\mathrm{~g} / \mathrm{l})$.

$\mathrm{Ha}$ - Aqueous concentration of nitric acid, $\mathrm{M}$.

Ho - Organic concentration of nitric acid, $M$. 


\section{Summary}

The SEPHIS computer program is currently being used to evaluate the effect of all process variables on the criticality safety of the HM 1st Uranium Cycle process in $\mathrm{H}$ Canyon. The objective of its use has three main purposes. 1) To provide a better technical basis for those process variables that do not have any realistic effect on the criticality safety of the process. 2) To qualitatively study those conditions that have been previously recognized to affect the nuclear safety of the process or additional conditions that modeling has indicated may pose a criticality safety issue. 3) To judge the adequacy of existing or future neutron monitors locations in the detection of the initial stages of reflux for specific scenarios.

Although SEPHIS generally over-predicts the distribution of uranium to the organic phase, it is a capable simulation tool as long as the user recognizes its biases and takes special care when using the program for scenarios where the prediction bias is non-conservative. The temperature coefficient used by SEPHIS is poor at predicting effect of temperature on uranium extraction for the $7.5 \% \mathrm{TBP}$ used in the HM process. Therefore, SEPHIS should not be used to study temperature related scenarios. However, within normal operating temperatures when other process variables are being studied, it may be used. Care must be is given to understanding the prediction bias and its effect on any conclusion for the particular scenario that is under consideration. Uranium extraction with aluminum nitrate is over-predicted worse than for nitric acid systems. However, the extraction section of the $1 \mathrm{~A}$ bank has sufficient excess capability that these errors, while relatively large, still allow SEPHIS to be used to develop reasonable qualitative assessments for reflux scenarios. However, high losses to the $1 \mathrm{AW}$ stream cannot be modeled by SEPHIS. 


\section{Background}

Historical HM Process in H-Canyon:

Typical HM feed consists of fuel tubes with a uranium-aluminum core ${ }^{5}$. Mercuric nitrate acts as a catalyst to the nitric acid dissolution process to dissolve the aluminum. Initial nitric acid concentrations of 4 to $8 \mathrm{M} \mathrm{HNO}_{3}$ are used in the dissolver. The solution acidity is depleted during the dissolution to less than $1 \mathrm{M}$ $\mathrm{HNO}_{3}$ (due to oxidation reactions with generation of $\mathrm{NO}_{\mathrm{x}}$ and $\mathrm{H}_{2} \mathrm{O}$ ). The solution containing the dissolved $\mathrm{Al}$, $\mathrm{U}, \mathrm{Np}$ and $\mathrm{Pu}$ is then transferred through head-end in batches. Head-end treatment of the solution consists of combinations of gelatin $/ \mathrm{MnO}_{2}$ strike(s) to remove silica and reduce the $\mathrm{Zr}$ and Nb content. The $\mathrm{MnO}_{2}$ strike is not currently required as the fuel available for dissolution is sufficiently aged that the $\mathrm{Zr}$ and $\mathrm{Nb}$ has already decayed to minimal levels. A centrifugation step is used to remove gelatin, $\mathrm{MnO}_{2}$ and any other solids. The $\mathrm{U}$ solution is then adjusted to make it suitable for 1st Uranium Cycle processing.

1st Uranium Cycle feed is $\sim 4 \mathrm{~g} \mathrm{U} / 1,>0.5 \mathrm{M} \mathrm{HNO}_{3},<2 \mathrm{M}$ aluminum nitrate with small amounts $\mathrm{Np}(\mathrm{IV})$, $\mathrm{Pu}(\mathrm{IV})$, and fission products. The $U$ and $\mathrm{Np}(\mathrm{IV})$ are extracted into the $7.5 \%$ TBP solvent in the $1 \mathrm{~A}$ bank. Pu is reduced by the FS in the $1 \mathrm{AS}$ stream to $\mathrm{Pu}(\mathrm{III})$ and exits the process in the $1 \mathrm{AW}$ stream. Aluminum nitrate in the extraction section increases the $\mathrm{U}, \mathrm{Np}$ and $\mathrm{HNO}_{3}$ distribution coefficient $\left(\mathrm{D}_{\mathrm{o} / \mathrm{a}}\right)$ in the extraction section due to "salting". The solvent retains the $U$ and $N p(I V)$ and both are transported to the $1 \mathrm{~B}$ bank where $N p(I V)$ is stripped out of the solvent by the $1 \mathrm{BX}$. The $1 \mathrm{BX}$ contains an intermediate $\mathrm{HNO}_{3}$ concentration such that

Figure 1. Current Flowsheet for HM 1st Uranium Cycle Process.

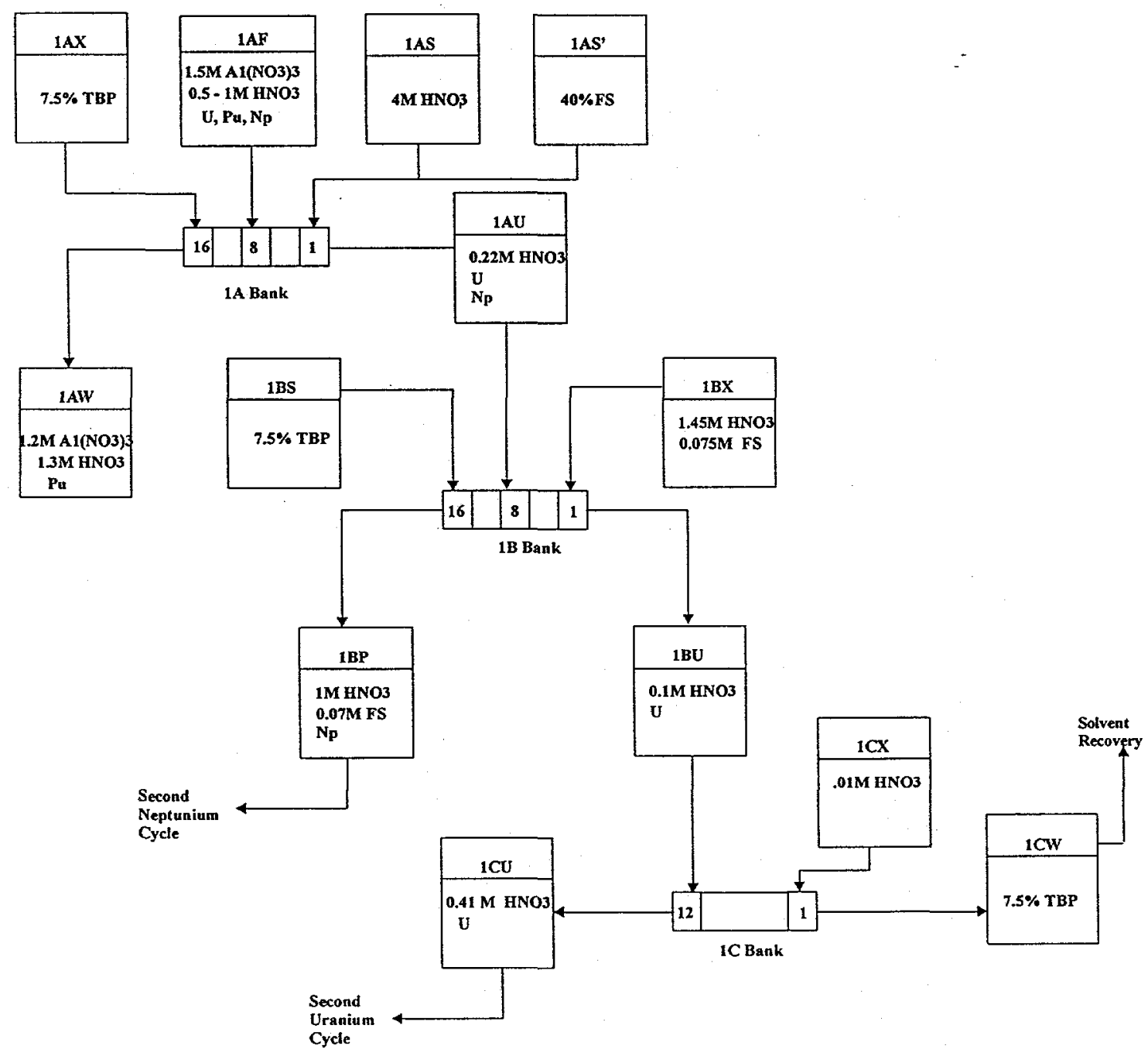


Table I. Operating Conditions, Limits and Assumptions for Modeling the HM 1st Uranium Cycle Process. $^{\text {s }}$

\begin{tabular}{|c|c|c|c|c|c|c|c|c|c|c|}
\hline & \multicolumn{3}{|c|}{ Flow Rate, $1 / \min$} & \multicolumn{3}{|c|}{ Temperature, C } & \multicolumn{4}{|c|}{ Concentration, $\mathrm{g} / \mathrm{l}, \mathrm{M}$ or Volume $\%$} \\
\hline & Minimum & Nonimal & Maxinun & Minimum & Nonimal & Maxinum & Minimum & Nonimal & Maxinum & \\
\hline \multirow[t]{3}{*}{$\mathrm{IAF}$} & 7.5 & 8.3 & 9.2 & 25 & 30 & 37 & & & 8.4 & $\mathrm{~g} / 1 \mathrm{U235}$ \\
\hline & & & & & & & 0.5 & & & $\mathrm{M}, \mathrm{HNO}_{3}$ \\
\hline & & & & & & & $\sim 1$ & 1.2 & 2 & $\mathrm{M}, \mathrm{ANN}$ \\
\hline $1 \mathrm{AX}$ & 13.7 & 14.6 & 15.3 & 35 & 40 & 44 & 7 & 7.5 & 8.5 & Vol $\%$ TBP \\
\hline IAS-A & 1.60 & 1.80 & 2.00 & & & & 4 & & & $\mathrm{M}, \mathrm{HNO}_{3}$ \\
\hline 1AS-FS & 0.13 & 0.11 & 0.16 & & & & & 0.12 & & $\mathrm{M}, \mathrm{FS}$ \\
\hline IAS (total) & 1.73 & 1.91 & 2.16 & 34 & 38 & 44 & 3.8 & & & $\mathrm{M}, \mathrm{HNO}_{3}$ \\
\hline IBS & 24.4 & 26.3 & 28.1 & 35 & 39 & 44 & 7 & 7.5 & 8.5 & Vol \% TBP \\
\hline $1 B X$ & 8.2 & 8.7 & 9.3 & 32 & 35 & 44 & 1.45 & & 1.6 & $\mathrm{M}, \mathrm{HNO}_{3}$ \\
\hline & & & & & & & & 0.075 & & $\mathrm{M}, \mathrm{FS}$ \\
\hline $1 \mathrm{CX}$ & 9.7 & 10.4 & 11.1 & 50 & 60 & 65 & 0.005 & 0.01 & 0.04 & $\mathrm{M}, \mathrm{HNO}_{3}$ \\
\hline
\end{tabular}

HM Assumptions:

Organic Phase Flows from stage to stage by Gravity Only

Aqueous is Pumped from stage to stage by mixer impellers

$P$ hase ratios in mixer stages are proportional to flow rate ratios

Phase ratios in settler stages are controlled by interface height in exiting stage at $2 / 3$ organic $1 / 3$ aqueous

Sephis adequately calculates temperatures of mixed streams

$-S$. Heat of organic $=0.321+0.078 *$ volume frac $\mathrm{TBP}, \mathrm{cal} / \mathrm{g} / \mathrm{C} \quad 0.3269$

$-S$. Heat of aqueous $=1 \mathrm{cal} / \mathrm{g} / \mathrm{C}$

\begin{tabular}{|c|c|c|c|c|}
\hline & & liters/stage & Aqueous & Organic \\
\hline \multirow{2}{*}{\multicolumn{2}{|c|}{ A, B, \& D Bank Mixer Volume, liters }} & 2.36 & 2.36 & 0 \\
\hline & & 9.439 & $9.439 * \mathrm{~A} /(\mathrm{O}+\mathrm{A})$ & $9.439 * 0 /(\mathrm{O}+\mathrm{A})$ \\
\hline \multirow{10}{*}{ C \& E Bank } & total & 11.8 & & \\
\hline & Settler Volume, liters & 21.1 & 21.1 & 0 \\
\hline & & 42.1 & 0 & 42.1 \\
\hline & total & 63.2 & & \\
\hline & Mixer Volume, liters & 6.637 & 6.637 & 0 \\
\hline & & 25.22 & $25.22 * \mathrm{~A} /(\mathrm{O}+\mathrm{A})$ & $25.22 * \mathrm{O} /(\mathrm{O}+\mathrm{A})$ \\
\hline & total & 31.857 & & \\
\hline & Settler Volume, liters & 84.93 & 84.93 & 0 \\
\hline & & 169.83 & 0 & 169.83 \\
\hline & total & 254.8 & & \\
\hline
\end{tabular}

$\mathrm{Np}$ (IV) is stripped from the solvent, but $U$ is retained until it is stripped in the $1 \mathrm{C}$ bank. FS is present in the $1 \mathrm{BX}$ to prevent oxidation of $\mathrm{Np}$ (IV) to $\mathrm{Np}(\mathrm{VI})$ which has a significantly higher $\mathrm{D}_{\mathrm{o} / \mathrm{a}}$. The $1 \mathrm{BS}$ stream is a solvent stream that scrubs the $U$ from the $1 \mathrm{BP}(\mathrm{Np})$ product. If the quantity of $\mathrm{Np}$ recovered is small, the $1 \mathrm{BP}$ stream will be neutralized and discarded to the tank farm along with the $1 \mathrm{AW}$ stream. $U$ is stripped out of the solvent by the $1 \mathrm{CX}$ stream $\left(0.01 \mathrm{M} \mathrm{HNO}_{3}\right)$ which is purified further in the 2nd Uranium cycle. Residual $\mathrm{U}$ remaining in the solvent in the $1 \mathrm{CW}$ stream is removed in the carbonate washers. A HM 1st Uranium Cycle process flowchart is shown in Figure 1 and current operating limits are listed in Table I.

All 1st cycle input streams (except the 1AF) are heated to between 32 and $65^{\circ} \mathrm{C}$ by steam powered heat exchangers. The $1 \mathrm{AF}$ stream is capable of being cooled (to remove radioactive decay heat) and is nominally at $30^{\circ} \mathrm{C}$. Inter-bank streams such as the $1 \mathrm{AU}$ and $1 \mathrm{BU}$ are not heated or cooled as they are transferred between banks (except for heat transfer through the piping). The inlet process streams are the only source of heat for the solvent extraction equipment.

During normal operation of the process, the solvent flow has sufficient capacity to extract all $U$ that is fed and transport it from the 1A bank, though the 1B bank until it is stripped in the $1 \mathrm{C}$ bank at a concentration no greater than the feed concentration. If process conditions exist in a portion of the bank that are less favorable to extraction, then the stage concentrations and inventories will be increased. Under extreme upset conditions, the process cannot remove the all the uranium fed to the bank and a build-up of inventory occurs. A solvent extraction process that is operating under conditions that result in a $U$ buildup within the bank is commonly 
referred to as being in "reflux". Countercurrent flow processes naturally tend to reflux. When the uranium concentration profile reaches a maximum at any stage other than the feed or product stage, the bank may be said to be refluxing uranium. However, this would only represent a potential nuclear safety problem if that maximum $U$ concentration were greater than the feed stream concentration ${ }^{14}$. Improper flowrate ratios alone can result in $U$ concentrations in the exit streams of any bank and while this does not represent a reflux condition, such operation can pose a nuclear safety problem if the resulting $U$ concentration is greater than 10.8 $\mathrm{g} \mathrm{U}_{235 \text { equivalent }} / 1^{14}$.

\section{Process Modeling:}

Starting in the 1960's, a number of computer programs were written to simulate solvent extraction processes. SOLVEX and SEPHIS are Fortran programs developed in the 1970's that built on the earlier work. Both the SOLVEX ${ }^{11}$ and SEPHIS ${ }^{4,7}$ programs solve the material balance equations for both unsteady and steady state solvent extraction processes, but take different approaches in how the $\mathrm{D}_{\mathrm{o} / \mathrm{a}}$ are provided to the code. SOLVEX was an advancement at the time it was developed in that it added the ability to input $\mathrm{D}_{\mathrm{o} / \mathrm{a}}$ data in tabular form (for interpolation) rather than use of polynomial type equations. SEPHIS attempted to utilize thermodynamically consistent equations to correlate $D_{0 / a}$ data that not only accounted for the effects of nitrate salting and uranium concentration, but also TBP concentration and temperature. This made it a useful tool for studying a wide variety of effects. However, since its $\mathrm{D}_{\mathrm{o} / \mathrm{a}}$ data entirely incorporated into Fortran code, it is not readily modifiable. Also the data utilized to correlate the $\mathrm{D}_{\mathrm{o} / \mathrm{a}}$ data relied heavily on 20 to $30 \%$ TBP data at relatively high uranium concentrations. For this reason, Bendixsen ${ }^{2}$ developed a low TBP specific program based on SEPHIS called ICPSEF to model the pulse columns used in the ICPP. These issues highlight accuracy problems with SEPHIS when dealing with the low uranium and TBP concentrations neeessarily used with an enriched uranium process.

As part of the development of the GTM for the TRUEX process, Argonne National Laboratory has developed a program that runs in an Excel environment as a macro ${ }^{6,18}$. This program is called SASSE and allows the calculation of steady-state material balances for counter-current flow solvent-extraction processes with user input of appropriate values of $D_{0 / a}$ and flowrates. While this program cannot perform unsteady state simulations, it is very easy to use when appropriate values of $D_{0 / 2}$ are available for input. It also allows ready : incorporation of any equations that are convenient for prediction of $\mathrm{D}_{\mathrm{o} / \mathrm{a}}$ based on component concentrations on individual stages.

Both SOLVEX and SEPHIS are written in Fortran and were developed with the intention of the programs being run on mainframe computers. In 1989, SEPHIS was ported to run in Microsoft Fortran on a PC in DOS by SRTC. This involved updating many of the input-output statements from statements that were no longer supported by the compiler. No calculation related changes were made at that time.

The most critical use of any of these programs is the recognition of operating conditions that in the actual process will cause reflux and a potentially unsafe condition. Process variables can be varied in the computer run and the calculated process inventory will rise and fall. By running these programs over a wide range of conditions, inventory trends are studied. The approach of reflux conditions results in convergence difficulties for the steady state solution of the material balances. None of these programs will converge to a steady state concentration profile when severe reflux conditions are specified as input parameters. Under mild reflux conditions, these programs may reach the limit of iteration (time or number of iterations) with little or no indication that a steady state material balance was not converged. With such a simulation, it is necessary for the operator to take steps to recognize when results are not steady state results.

Distribution Data:

Validation of any solvent extraction simulation program for the HM process requires a good set of uranium extraction data to compare the program against. Experimental $U$ extraction data for the original HM process was developed in the $1950^{\prime} \mathrm{s}^{1,8,12}$. Additional data was taken by Thompson when the $1^{\text {st }}$ Cycle process was changed to $7.5 \%$ TBP $^{13,14,15,16,17 .}$ DP-1500 was compiled in the later 1970's and documented both the process and equipment details along with extraction data ${ }^{5}$. These provide the three main authoritative sources of $\mathrm{D}_{\mathrm{o} / \mathrm{a}}$ information that are applicable to the HM process today. A larger body of data exists at the higher TBP concentrations typically used in the PUREX process, but this is not particularly useful for modeling the HM process $^{3.9}$. DP-1384 contains extensive uranium extraction data for 7.5 volume percent TBP over a wide range of nitric acid and uranium concentrations for 23,45 , and $60^{\circ} \mathrm{C}$. It also has a limited amount of data for aluminum nitrate/HNO3 salted extraction at the same temperatures. DP-53 contains some uranium extraction data for 2 to 10 volume percent TBP for the temperature range of 25 to $45.9^{\circ} \mathrm{C}$. For this effort, DP-1384 was 
the primary source of $\mathrm{D}_{\mathrm{o} / \mathrm{a}}$ acid salted data, supplemented by DP-53. DP-1500 and DP-1384 were relied on for aluminum nitrate salted data.

\section{Calculational Methodology:}

Use of a PC rather than a mainframe computer has the advantage that retrieval of output is quick and simple and output can be readily transferred to other desktop applications for analysis and study. During this work SEPHIS output was directly imported as text into Word and tables within the output were then converted to actual tables using the "Convert text to table" option of Word. This allowed data transfer to either Excel or Sigmaplot for preparation of graphs to visualize the results simulated by SEPHIS. A standard Excel spreadsheet was set up that allowed for the output of a series of SEPHIS cases to be imported into a spreadsheet separating cells using the delimiter " $\mid$ " used in SEPHIS to separate columnar data. Other sheets of the spreadsheet then read the values of the cells from the first sheet for each case in sequence. Standard graphs compared the different cases contained in the run. This allowed rapid preparation of a graphical presentation of the results of the study of a variable.

The punched profile output was also used in a similar manner. This file contains profiles for concentrations and temperature for both the aqueous and organic phases for each stage. This punch file was directly imported into Excel and $D_{o / 2}$ calculated. This technique was also used to produce predictions for $D_{o / a}$ to

Table II. Method for Calculation of $\mathrm{D}_{\mathrm{o} / \mathrm{a}}$ Using SEPHIS. compare with literature data. Table II lists the Inputs:

- $10 \quad$ Ipm Aqueous Flow (T, U, $\mathrm{HNO}_{3, \mathrm{a}}$ )

- 0.0001 lpm Organic Flow (T, TBP)

- Single Isothermal Stage (All streams at same T)

Calculated Outputs:

- 101 Ipm Aqueous $\left(\mathrm{T}, \mathrm{U}_{2}, \mathrm{HNO}_{3, \mathrm{z}}\right)$

- $0.0001 \mathrm{lpm}$ Organic Flow (T, TBP, $\mathrm{U}_{0}, \mathrm{HNO}_{3, \mathrm{o}}$ )

- $\mathrm{D}_{\alpha / 2}$ for $\mathrm{U}=\mathrm{U}_{\alpha} / \mathrm{U}_{\mathrm{a}}$

Since Aqueous Flow $\gg$ Organic Flow, the extraction of $\mathrm{U}$ and HNO3 is insignificant to the material balance assumptions and setup that was used to predict a single data point using a single isothermal stage. By inputting a data set that contains a similar case for each data point to be predicted by SEPHIS, a file containing 2 lines of output for each point was produced. Once a standard Excel file was created, copies of that file were created and new data pasted into the punched output sheet. This greatly reduced the effort to analyze the results and minimized the potential. for transcription errors.

Operation of SASSE was fairly straightforward. The "sasse_generator" macro was loaded into Excel and the macro run to setup a new process simulation spreadsheet ${ }^{18}$. After input of the number of sections, stages and components, a new spreadsheet for the process was created. Input flowrates and concentrations had to be entered as well as entering values or equations for $D_{o / a}$. It is necessary to activate the "Iteration" feature of the "Calculation" tab of the "Options" tab of the Tools command. This is how SASSE solves the material balances for the counter-current-flow solvent extraction equations. Since some versions of Excel have reported a recalculation "bug", special attention was given to forcing a "Cntl-Alt-F9" recalculation after any changes were made to a SASSE spreadsheet. Once the HM process was set up in SASSE, the spreadsheet was then copied so that different conditions could be simulated without recreating the overall spreadsheet.

One significant difference in nomenclature is that SASSE adopts a stage numbering convention that is opposite that which has always been used at SRS. Whereas SRS numbers stages such that the organic flow travels from high stage numbers to low, SASSE numbers stages such that organic flows from low to high. This requires a translation of stage designation to be made to compare the results of the two programs and care has to be taken to place the feed stage to a bank on the correct stage. 
Results and Discussion:

SEPHIS Predictions with Aluminum Nitrate Present

Material Balance Checks: The extraction section of the $1 \mathrm{~A}$ bank contains significant amounts of aluminum nitrate. This is accounted for in SEPHIS as non-extractable nitrate and is input as 3 times the aluminum molarity. The correlation used in SEPHIS to calculate aqueous density significantly over-predicts the density of solutions containing significant amounts of aluminum nitrate. Since SEPHIS constantly converts units between moles/liter and moles $/ \mathrm{kg}$, the aqueous density errors could significantly affect the material balance. This potential problem was investigated by running SEPHIS with both $1.2 \mathrm{M}$ and $2 \mathrm{M} \mathrm{Al}$ and extracting the $U D_{0 / a}$ that SEPHIS calculated. The same input conditions and $D_{0 / a}$ values were then copied into SASSE and the $U$ profiles between the two programs were compared. Table III shows edited results of the $2 \mathrm{M} \mathrm{Al}$

Table III. SEPHIS versus SASSE Material Balance Comparison.

$\left(U_{a}\right.$ Difference is calculated as $\left(U_{2}\right.$ SEPHIS $-U_{2}$ SASSE)/U, SEPHIS *100\%.)

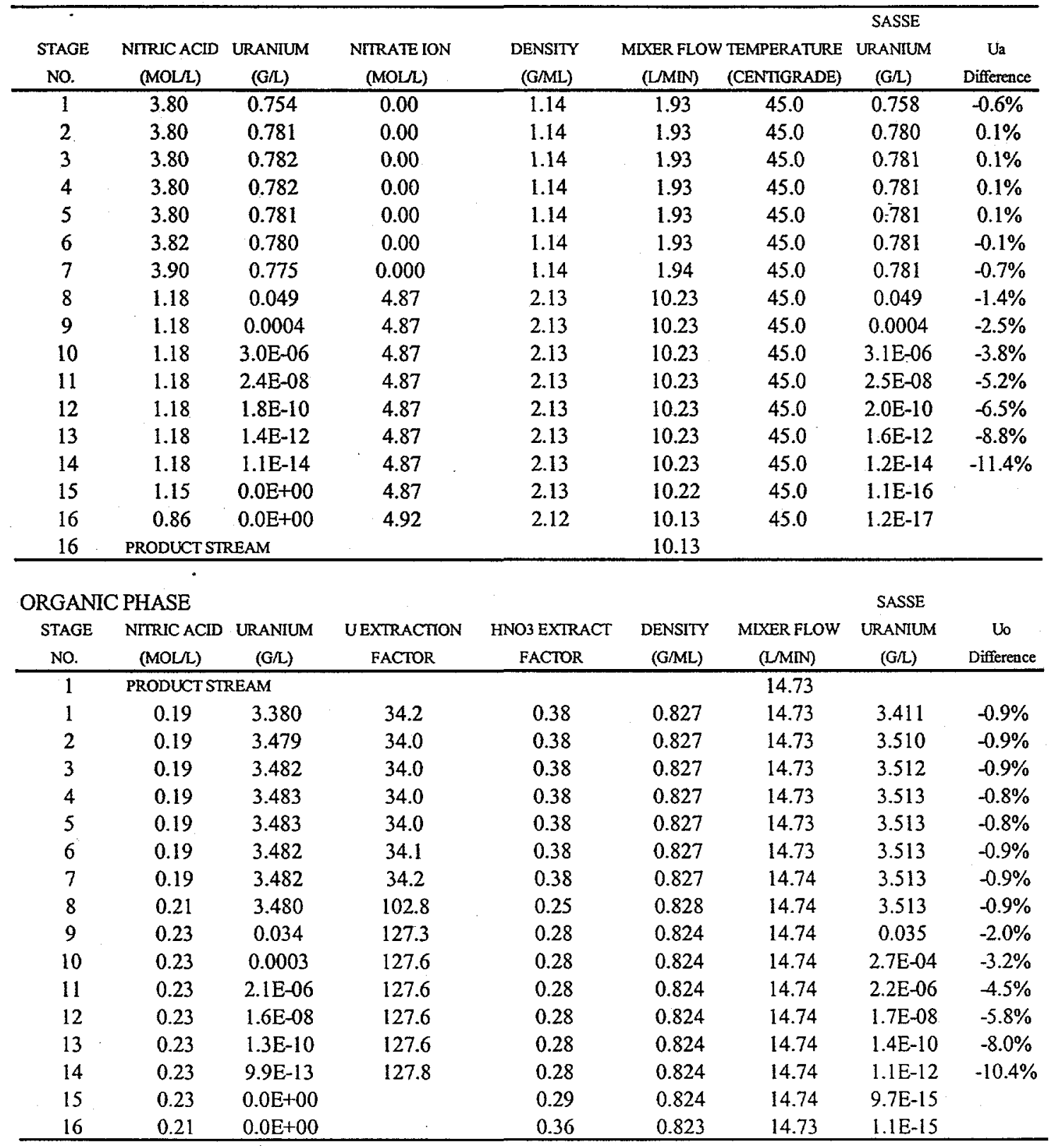


comparison for 1A bank (both extraction and scrub sections). The scrub section shows differences in $U$ concentration of up to $1 \%$ and the extraction section shows differences of 2 to $10 \%$. The differences in the extraction section are differences between small concentrations of $U$ which don't appear to be a significant problem. The differences in the scrub section are not large enough to be of serious concern and although not investigated in depth, may be due to rounding differences in the calculations or the difference between the use of an iterative solution method in one program and a 4th order Runga Kutta numerical integration method in the other. Overall, the relatively small differences in the $U$ material balance indicate that the large differences in aqueous density do not seriously affect the $U$ stage to stage profiles. The good agreement between the two independent programs validates the overall material balance and stage to stage profiles with the assumption that good values of $D_{0 / a}$ are being provided.

$D_{0 / a}$ Prediction: SEPHIS calculates the $D_{0 / 2}$ based on a pseudo mass-action equilibrium constant ${ }^{4,7}$ that is dependent on a term that equates to the total nitrate in the aqueous phase. DP- $1500^{5}$ contains a graph of $\mathrm{D}_{0 / 2}$ for $U$ from $1.6 \mathrm{M} \mathrm{ANN} / 0.5 \mathrm{M} \mathrm{HNO}$ into 7.5 volume $\% \mathrm{TBP}$ as $\mathrm{U}_{\mathrm{a}}$ is varied for both 23 and $45^{\circ} \mathrm{C}$. This graph has been digitally reproduced and SEPHIS predictions for both 23 and $45^{\circ} \mathrm{C}$ have been added and are included as Figure 2. Inspection of this graph shows that SEPHIS significantly over-predicts the $D_{0 / 2}$ for both temperatures. A numerical comparison showed that for less than $2 \mathrm{~g} / 1 \mathrm{U}_{\mathrm{a}}$, SEPHIS over-predicted the DP-1500 curves by $25-300 \%$ for $23^{\circ} \mathrm{C}$ and by $40-350 \%$ for $45^{\circ} \mathrm{C}$. These comparisons agree with the past observations that SEPHIS tends to under-predict losses to the AW stream. Due to the small U inventories involved on stages where aluminum nitrate is present and the relatively large $D_{o / a}$ 's that experimentally exist when $>1 \mathrm{M}$ aluminum nitrate is present, it does not appear these prediction errors pose a serious problem. The errors could be reduced by artificially lowering the amount of aluminum used in the input to SEPHIS or by using SASSE with more realistic values for $\mathrm{D}_{\mathrm{o} / \mathrm{a}}$.

Figure 2. SEPHIS Predictions as a Function of $U_{a}$ for DP-1500 Aluminum Nitrate System.

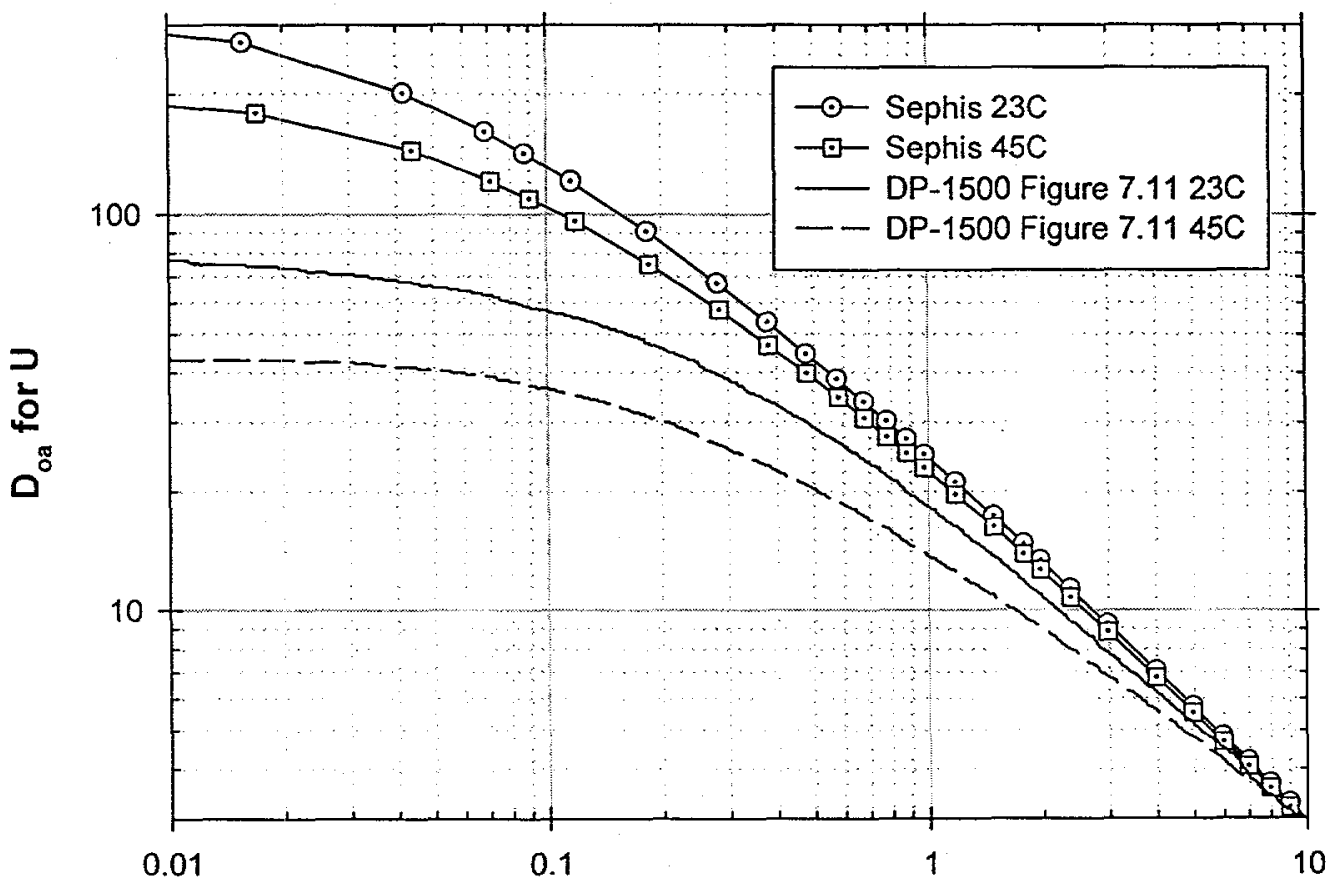

$\mathrm{Ua}, \mathrm{g} / \mathrm{I}$ 
Figure 3. SEPHIS Predictions of $\mathrm{UD}_{\mathrm{o} / \mathrm{a}}$ for DP-1384 $\mathrm{HNO}_{3}$ Systems $23^{\circ} \mathrm{C}$.

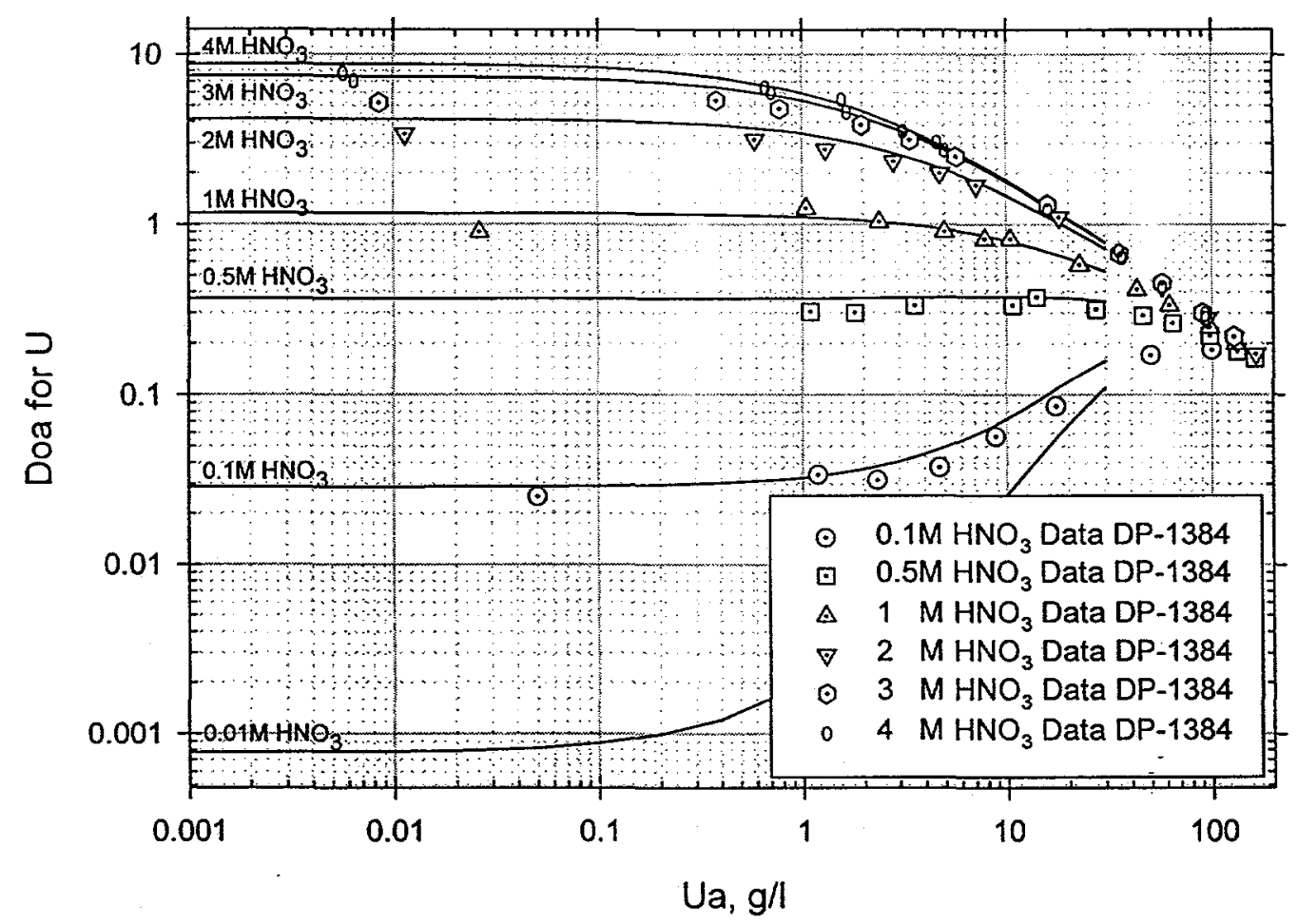

SEPHIS Predictions with Nitric Acid Salting Only

$D_{0 / a}$ Prediction: When nitric acid is the only salting agent present SEPHIS still calculates the $D_{o / a}$ based on the same pseudo mass-action equilibrium constant with dependence on total nitrate in the aqueous phase. DP- $53^{12}$ and DP- $1384^{16}$ provide data on the $\mathrm{D}_{\mathrm{o} / \mathrm{a}}$ for $\mathrm{U}$ from $\mathrm{HNO}_{3}$ solution into $7.5 \% \mathrm{TBP}$ at temperatures between 23 and $60^{\circ} \mathrm{C}$. Figures 3,4 and 5 show a comparison of $D_{o / a}$ for $U$ between SEPHIS predictions and the data of DP-1384. Isotherms of 23,45 and $60^{\circ} \mathrm{C}$ are shown as functions of both $\mathrm{U}_{\mathrm{a}}$ and $\mathrm{HNO}_{3}$. The data are also included as tables V, VI, and VII in the appendix.

Figure 6 shows the error of SEPHIS in predicting $D_{o / a}$ for $U$ as a function of $U_{a}$ for the data from DP53 and DP-1384. It shows a wide scatter but SEPHIS generally over-predicts the data by $20 \%$. There appears to be a trend toward improved prediction at higher $U_{\mathrm{a}}$ concentrations. Figure 7 contains the same data, but plotted as a function of the volume percent TBP. The trends of better fit at either higher TBP or higher $U_{a}$ concentrations was expected due to the sources of data used in the SEPHIS correlation. Figure 8 also contains the same data, but plotted as a function of temperature. It appears clear from this graph that SEPHIS does not accurately account for the effect of temperature for the 2.5 to $10 \%$ TBP data referenced in this work. It appears that SEPHIS increasingly over-predicts the $D_{0 / a}$ at higher temperatures. Figure 9 is still the same data, but this time plotted as a function of aqueous acid concentration. There is not an obvious trend in looking at this plot. 
Figure 4. SEPHIS Predictions of $\mathrm{UD}_{\mathrm{o} / \mathrm{a}}$ for DP-1384 $\mathrm{HNO}_{3}$ Systems $45^{\circ} \mathrm{C}$.

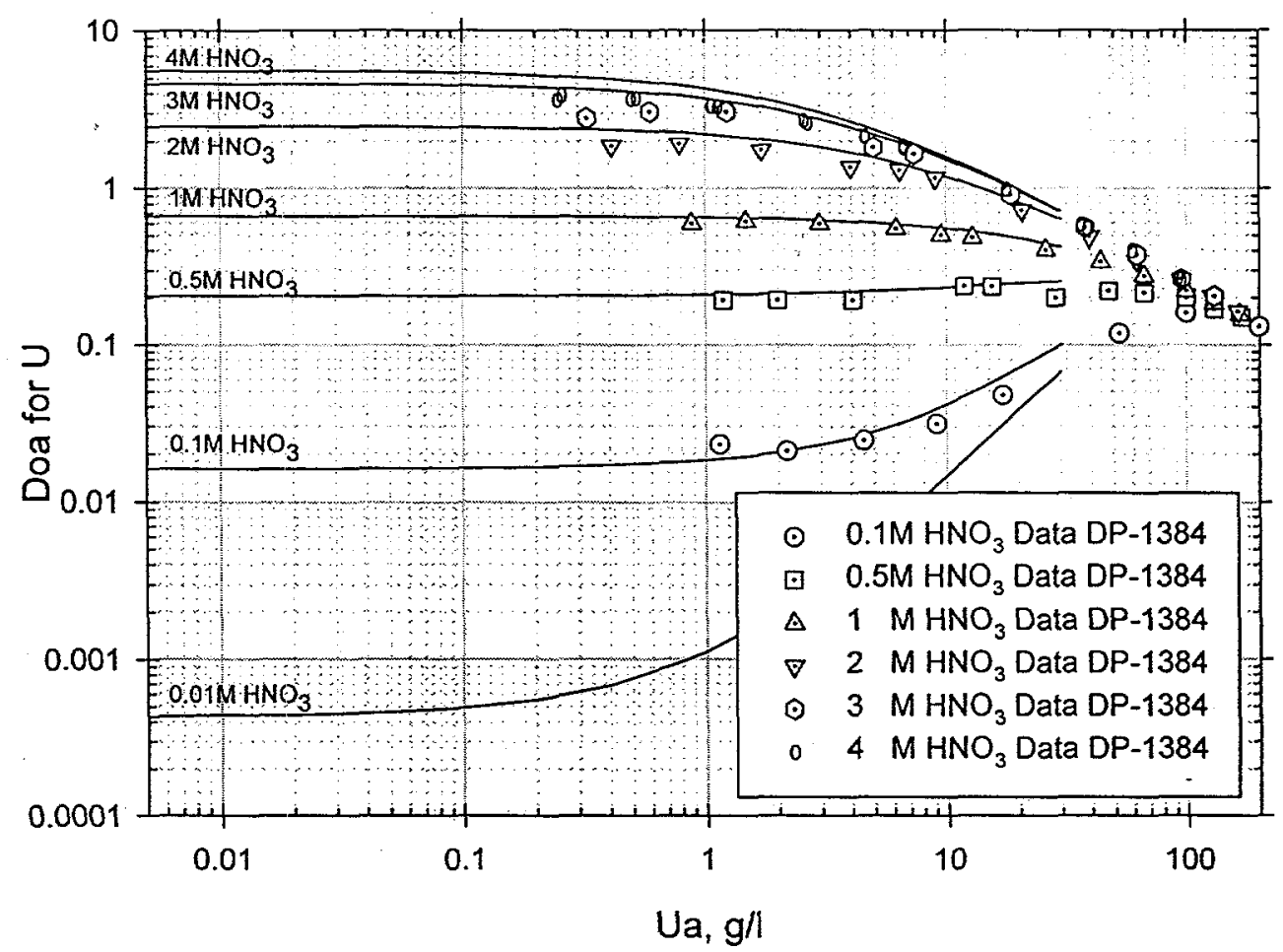

Figure 5. SEPHIS Predictions of $\mathrm{U} \mathrm{D}_{\mathrm{o} / \mathrm{a}}$ for DP- $1384 \mathrm{HNO}_{3}$ Systems $60^{\circ} \mathrm{C}$.

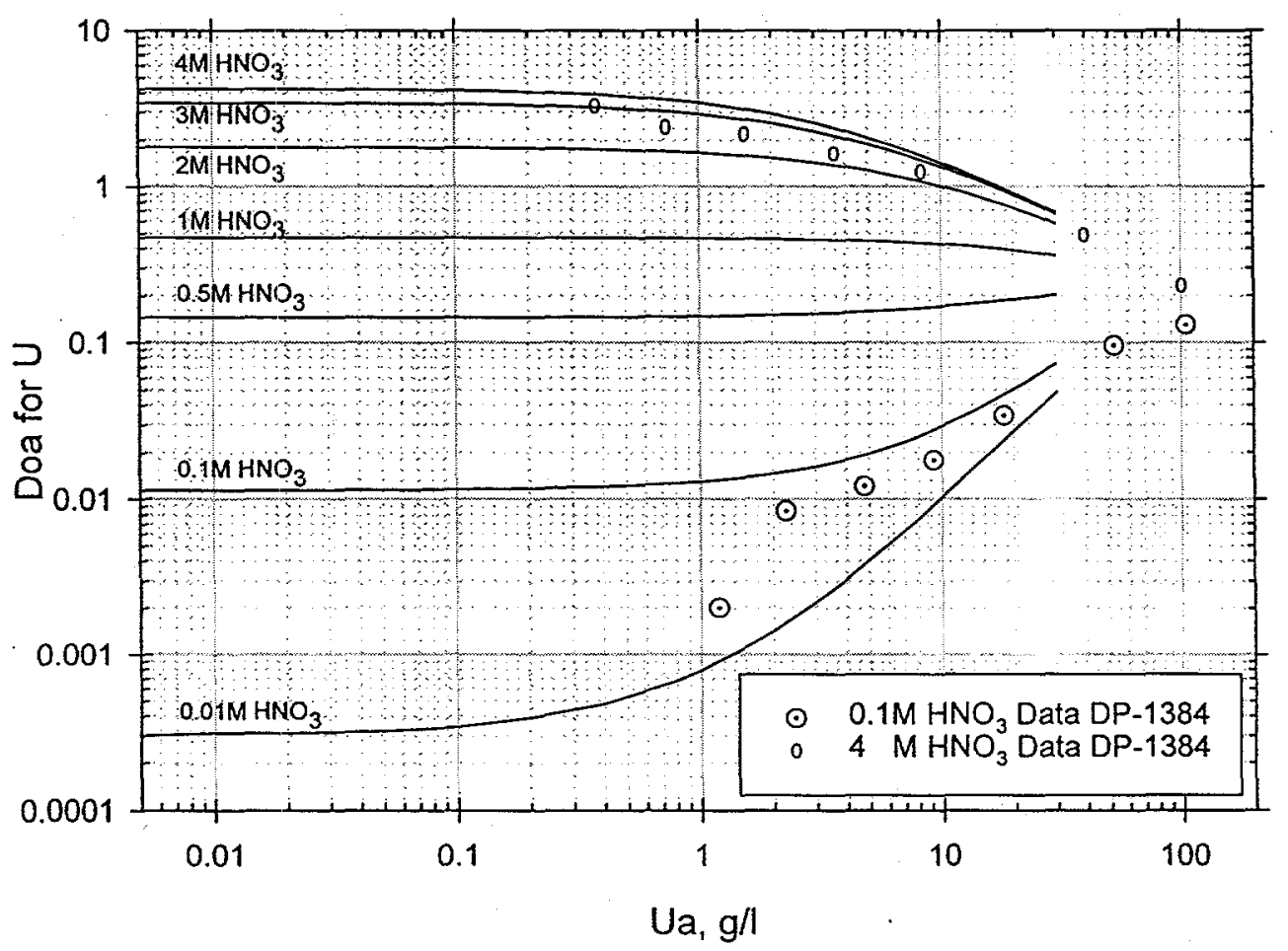


Figure 6. SEPHIS Error as a Function of $U_{\mathrm{a}}$ Concentration.

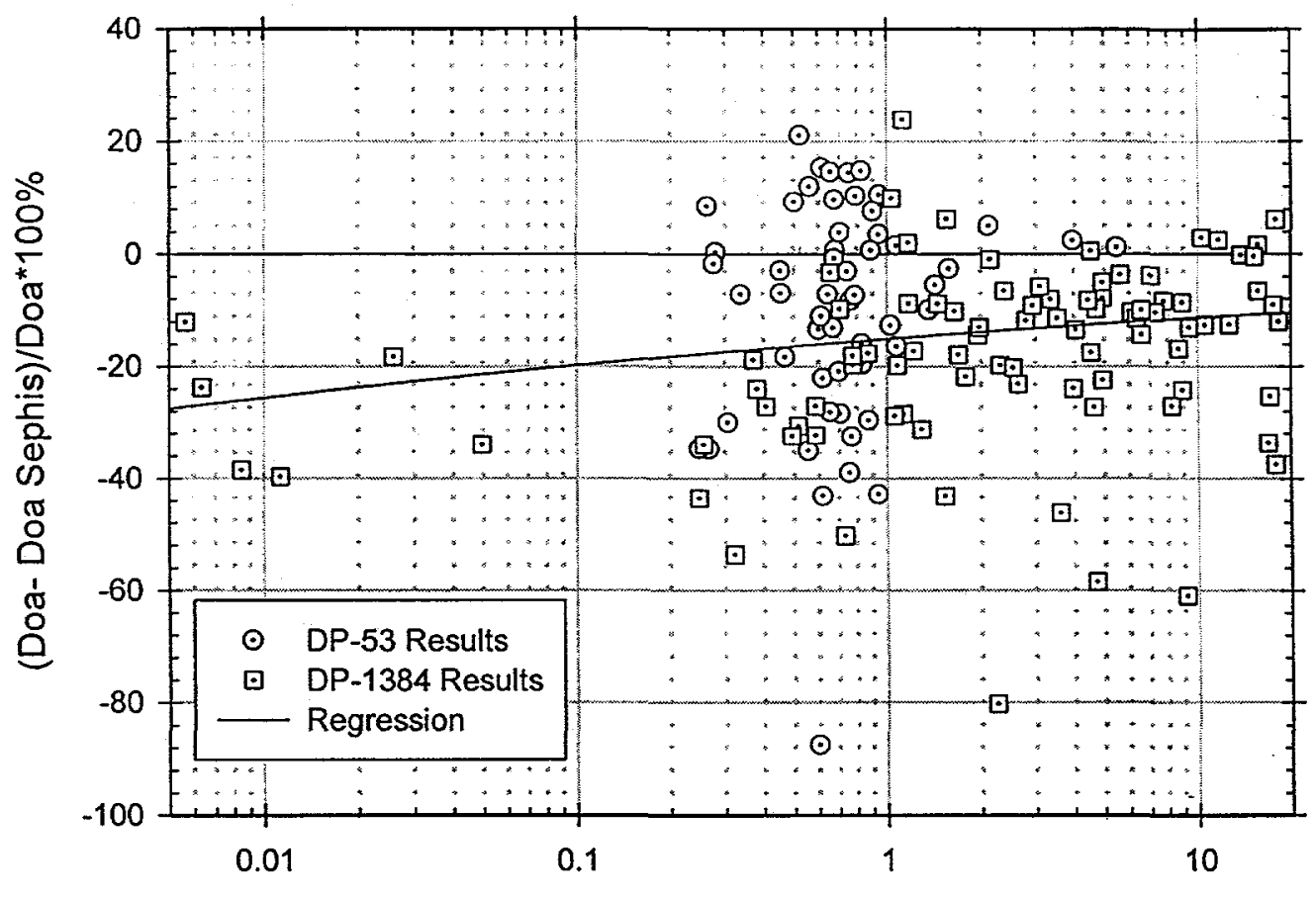

Ua, g/l

Figure 7. SEPHIS Error as a Function of Volume Percent TBP.

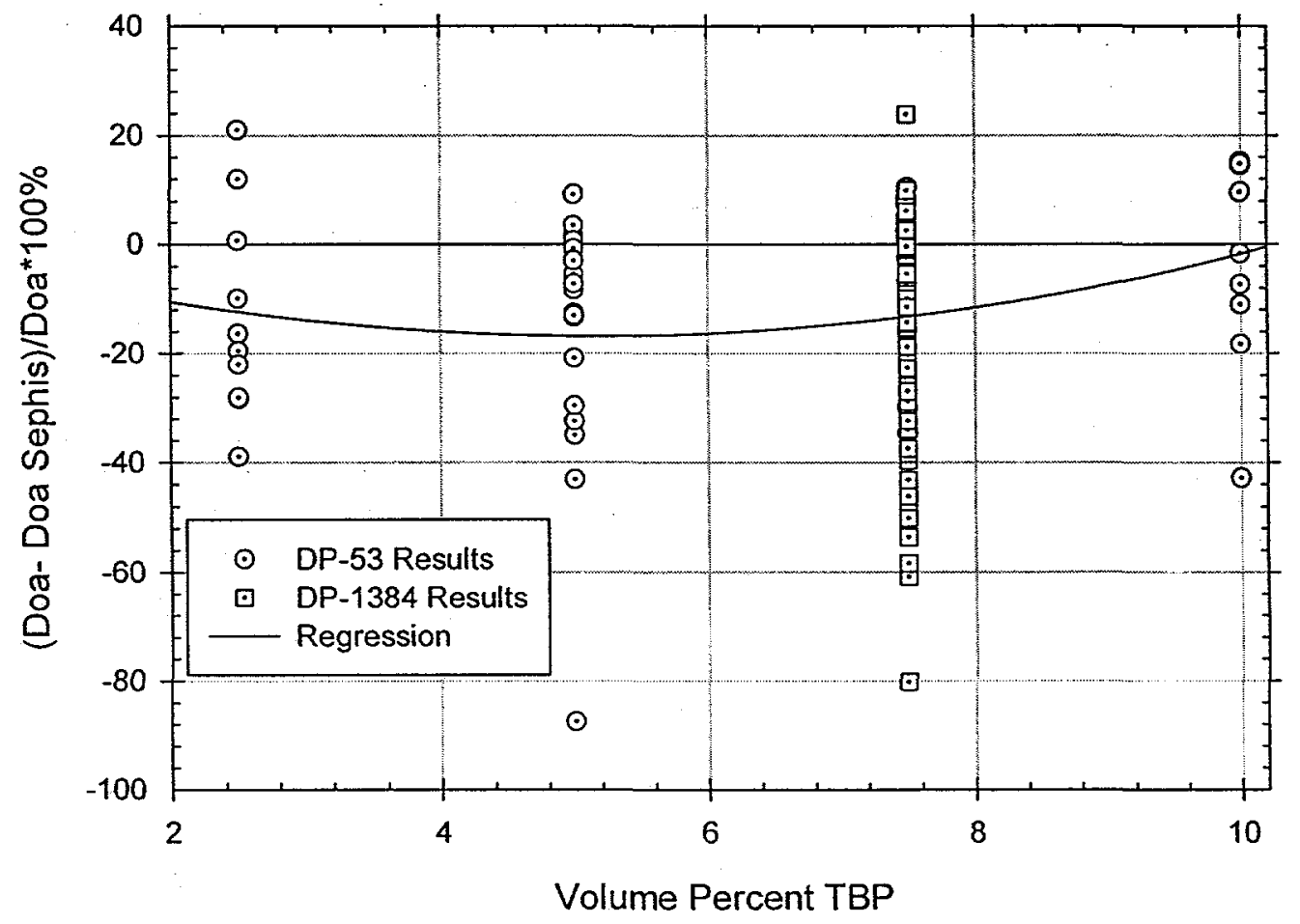


Figure 8. SEPHIS Error as a Function of Temperature.

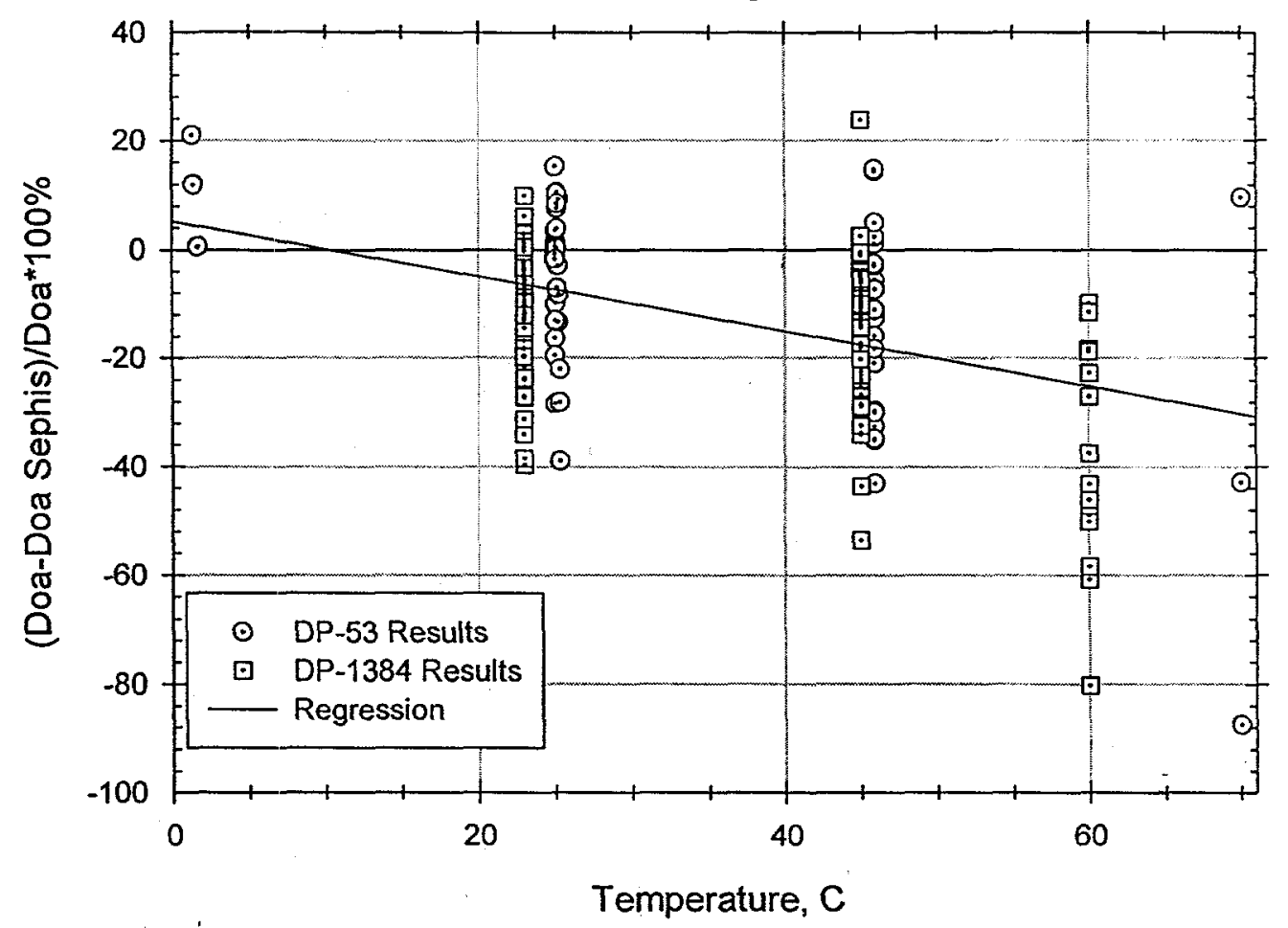

Further investigation of the influence of temperature on SEPHIS prediction of $U D_{0 / 2}$ has found that SEPHIS has based its temperature correction on an Arrhenius model ${ }^{4,13}$ with a temperature coefficient that apparently under-predicts the response of $\mathrm{D}_{\mathrm{o} / \mathrm{a}}$ to temperature for $7.5 \%$ TBP solvent. This results in the tendency of SEPHIS to over-predict the $D_{0 / a}$ at higher temperature. Figure 10 shows an Arrhenius plot of $\log \left\{\mathrm{D}_{\mathrm{o} / \mathrm{a}}(\mathrm{t}) / \mathrm{D}_{\mathrm{o} / \mathrm{a}}\left(\mathrm{t}_{\mathrm{o}}\right)\right\}$ vs. $1 / \mathrm{T}$ for DP-53 data at various $\mathrm{HNO}_{3}$ as well as the corresponding SEPHIS predictions. Inspection of the SEPHIS code indicates the possibility of improving the $\mathrm{D}_{\mathrm{o} / \mathrm{a}}$ predictions by adjusting the single temperature coefficient in the code to a value that better represents $U$ behavior with $7.5 \% \mathrm{TBP}$. However, correction of the model and validation of the corrected model was beyond the time constraints of the current report.

SEPHIS does not take into account any effects of heats of mixing or reaction into its temperature calculations. It assumes a constant specific heat for each phase $(1 \mathrm{cal} / \mathrm{g} / \mathrm{C}$ for aqueous phases and $0.321 \mathrm{cal} / \mathrm{g} / \mathrm{C}$ for pure n-paraffin and $0.399 \mathrm{cal} / \mathrm{g} / \mathrm{C}$ for pure TBP) and no molecular interaction between any of the species. Since there are interactions between TBP-U-HNO3-water and even TBP-n-dodecane has volume and enthalpy changes of mixing (indicating non-ideal behavior), these assumptions appear to be somewhat primitive. However the extent of errors in the temperature profile generated by these assumptions are not easy to quantify with the very limited data that is available to compare against. 
Figure 9. SEPHIS Error as a Function of $\mathrm{HNO}_{3}$ Concentration.

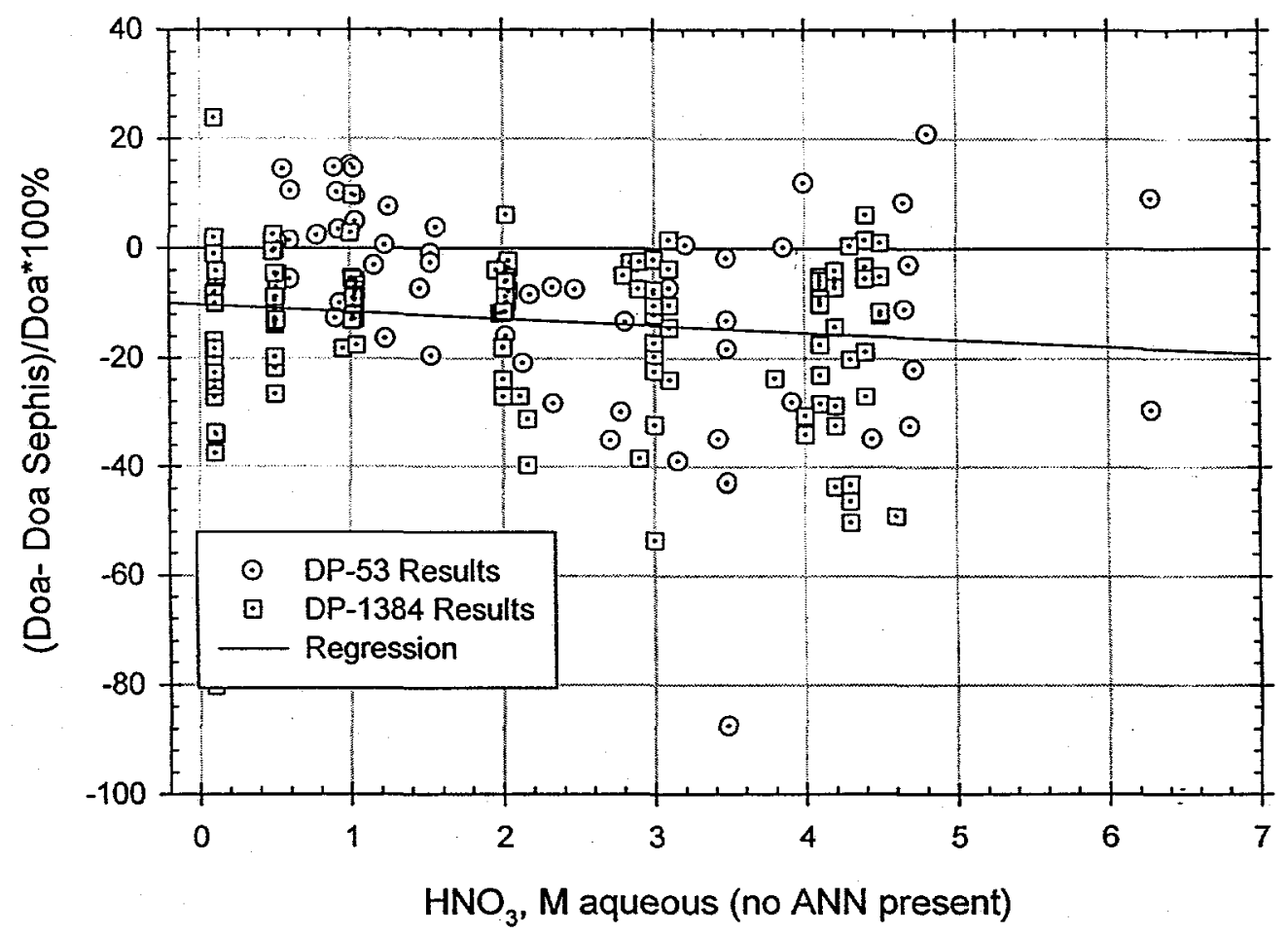

Figure 10. Comparison of SEPHIS Temperature Coefficient for U $D_{o / a}$ with DP-53 Table VIII Data.

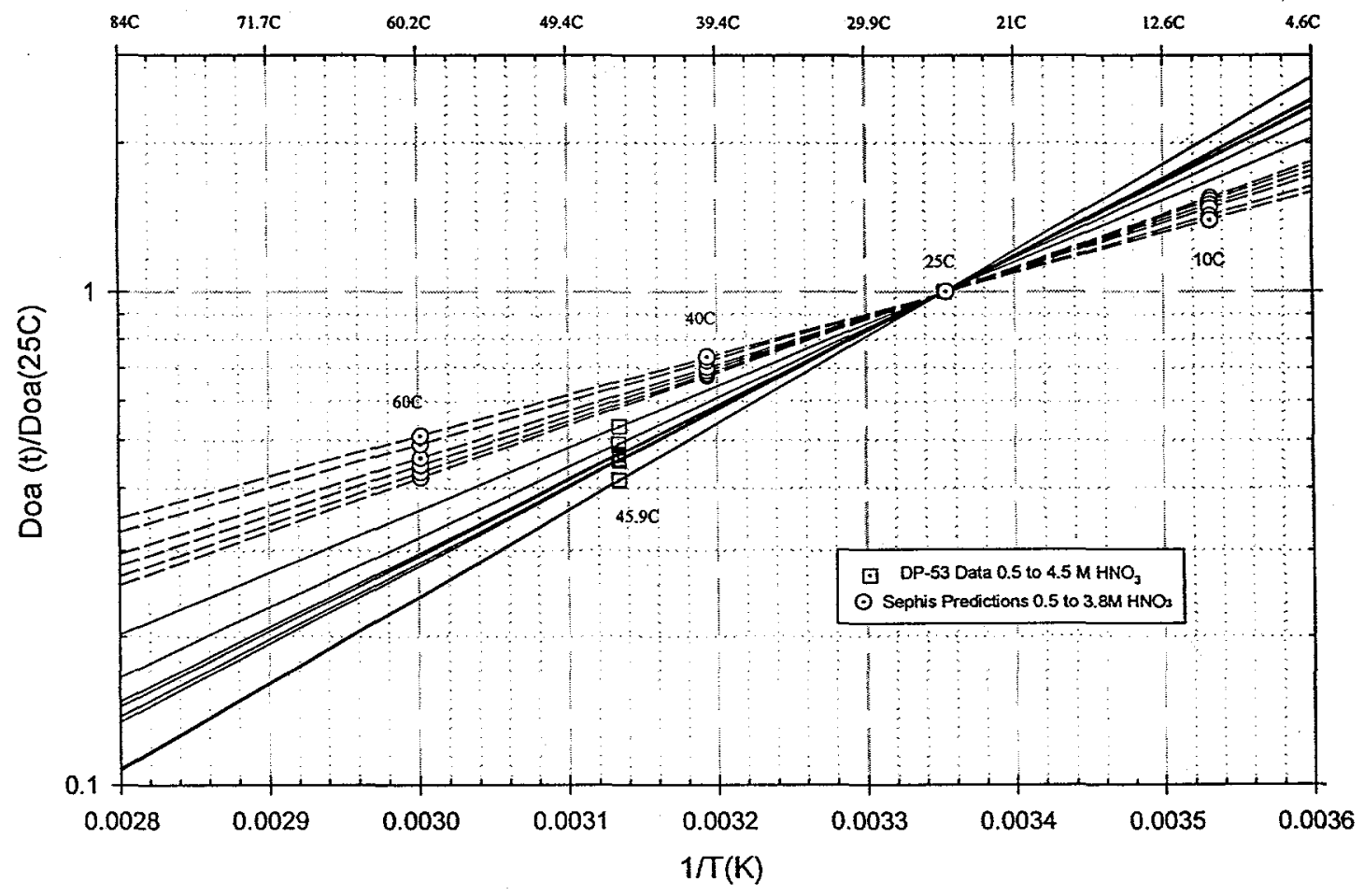




\section{Application of SEPHIS to Analyze for Potential U Reflux Conditions}

Since SEPHIS is being used to identify possible operating conditions that could cause unsafe uranium concentrations, it is important to recognize when it might fail to detect potential reflux conditions. Certainly SEPHIS 's $\mathrm{D}_{\mathrm{o} / \mathrm{a}}$ models have a limited accuracy when applied to a $7.5 \% \mathrm{TBP}$ solvent extraction process such as $\mathrm{HM}$ and generally over-predict the $\mathrm{D}_{\mathrm{o} / \mathrm{a}}$. When a process variable is being studied for a potential reflux effect, it is recommended that the variable be varied far enough beyond its operating range so that the SEPHIS predictions span the full range of $D_{o / a}$ expected (including the model bias). Analyzing conditions only within the operating limits of the variable may allow a reflux scenario to remain unnoticed if the model bias is nonconservative. The analysis of this report indicates that scenarios involving temperature must be very carefully evaluated as SEPHIS does not have the capability to accurately predict temperature effects on $U_{0 / a}$. Careful modeling of the applicable data in DP-53 and DP-1384 is needed to correct the temperature coefficient of SEPHIS. Even then, a thorough evaluation of the bias of the modified model should be made. Another approach would be to use SASSE to supplement SEPHIS in looking at the steady state solutions for temperature scenarios. This also requires careful modeling of the same data set, but would avoid alteration of the Fortran code.

\section{Uncertainies}

There are both experimental and calculational uncertainties throughout this work that can affect the conclusions of this work. The experimental $\mathrm{D}_{\mathrm{o} / \mathrm{a}}$ values from DP-53 and DP-1384 are by far the best data available for evaluating the HM process, but a direct comparison will show discrepancies between these sets of data. No attempt to arbitrate between these data sets was made. The temperature related errors are large enough that they may mask some other prediction error and prevent its identification. The aluminum salting effects on $D_{o / a}$ were not exhaustively analyzed as the reflux issues in the $1 \mathrm{~A}$ bank were not very sensitive the extraction portion of the process due to the large values of $\mathrm{D}_{0 / \mathrm{a}}$ involved. Large errors involving salting effects here just do not affect the conclusions. The prediction error is generally small enough that errors other than temperature errors are not a serious limitation of the use of this program as long as the general limitations of SEPHIS as a computer model are not forgotten. The heat capacity limitations in SEPHIS will introduce additional uncertainty when extreme values of temperature are involved. Under nominal temperature conditions, the opportunity for significant error caused by specific heat appears to be minimal. Certainly other conditions that can affect the real process (such as low interfacial tension, incomplete phase separation and DBP content of solvent) are far beyond the capability of SEPHIS or any other existing program to identify. 


\section{References}

1. D. P. Ames, D. G. Karraker, "Distribution of Uranyl Nitrate Between $\mathrm{Al}\left(\mathrm{NO}_{3}\right)_{3}$ and Tributyl Phosphate", DP-275, E. I. Du Pont de Nemours \& Co, Savannah River Laboratory, Aiken, SC, (March, 1958).

2. L. Bendixsen, "ICPSEF: A Users Manual for the Computer Mathematical Model of the ICPP Purex Solvent Extraction System", ENICO-1124, Exxon Nuelear Idaho Co, Idaho Falls, ID, (November, 1982)

3. J.W. Codding, W.O. Haas, F.K. Heumann, "Equilibrium Data for Purex Systems", KAPL-602, General Electric Co., Knolls Atomic Power Laboratory, Schenectady, NY, (November 26, 1951)

4. W. S. Groenier, "Calculation of the Transient Behavior of a Dilute-Purex Solvent Extraction Process having Application to the Reprocessing of LMFBR Fuels", ORNL-4746, Union Carbide Corp, Oak Ridge National Laboratory, Oak Ridge, TN, (April, 1972)

5. M. L. Hyder, W. C. Perkins, M. C. Thompson, G. A. Burney, E. R. Russell, H. P. Holcomb, L. F. Landon, "Processing of Irradiated Enriched Uranium Fuels at the Savannah River Plant", DP-1500, E. I. Du Pont de Nemours \& Co, Savannah River Laboratory, Aiken, SC, (April, 1979)

6. R. A. Leonard, M. C. Regalbuto, “A Spreadsheet Algorithm for Stagewise Solvent Extraction", Sol. Extr. and Ion Exch., 12(5), 909-930, (1994)

7. D. Mitchell, "Sephis-Mod4: A Users Manual to a Revised Model of the Purex Solvent Extraction System", ORNL-5471, Union Carbide Corp, Oak Ridge National Laboratory, Oak Ridge, TN, (May, 1979)

8. S. G. Parker W. E. Prout and T.H. Siddall,, "Solvent Extraction of Enriched Uranium", DP-122, E. I. Du Pont de Nemours \& Co, Savannah River Laboratory, Aiken, SC, (1955)

9. G.Petrich, Z. Kolarik, "The 1981 Purex Distribution Data Index", KfK 3080 PWA 94/80, Institut Fur Heisse Chemie Projekt Wiederaufarbeitung und Abfallbehandlung, Karlsruhe, (January, 1981)

10. Science and Technology of Tributyl Phosphate, Volume I: Synthesis, Properties, Reactions and Analysis", W. W. Schulz, J. D. Navratil, A.S. Taalbot, Editors, CRC Press, 1984, pg 179.

11. W. C. Scotten, "SOLVEX- A Computer Program fro Simulation of Solvent Extraction Systems, DP-1391, E. I. Du Pont de Nemours \& Co, Savannah River Laboratory, Aiken, SC, (September, 1975)

12. T.H. Siddall, S. G. Parker and W. E. Prout, "Equilibrium Distribution Data for Purex and Similar Extraction Processes", DP-53, E. I. Du Pont de Nemours \& Co, Savannah River Laboratory, Aiken, SC, (July, 1957)

13. M. C. Thompson, "Additional Data on Solvent Extraction of Enriched Uranium in $221-\mathrm{H}$ using $7.5 \%$ TBP", DPST-73-477, E. I. Du Pont de Nemours \& Co, Savannah River Laboratory, Aiken, SC, (October $29,1973)$

14. M. C. Thompson, "Nuclear Safety Evaluation of Solvent Extraction with 7.5\% TBP in H-Area", DPST73-476, E. I. Du Pont de Nemours \& Co, Savannah River Laboratory, Aiken, SC, (December 6, 1973)

15. M. C. Thompson, R. L. Shankle, "Calculation of Uranium Inventories in Mixer-Settlers During Solvent Extraction with 7.5 \% TBP", DP-1357, E. I. Du Pont de Nemours \& Co, Savannah River Laboratory, Aiken, SC, (August, 1974) 
16. M. C. Thompson, B. E. Murphree, R. L. Shankle, "Equilibrium Distribution of Uranyl Nitrate Between Nitric Acid and 7.5 Vol \% TBP", DP-1384, E. I. Du Pont de Nemours \& Co, Savannah River Laboratory, Aiken, SC, (October, 1975)

17. M. C. Thompson, "Improvements in Processing Highly-Enriched Uranium", DPST-77-212, E. I. Du Pont de Nemours \& Co, Savannah River Laboratory, Aiken, SC, (January 14, 1977)

18. G. F. Vandegrift, D. J. Chaiko, D. B. Chamberlain, L. Chow, J. M. Copple, D. R. Fredrickson, R. J. Jaskot, J. D. Kwok, R. A. Leonard, J. B. Rajan, L. Reichley-Yinger, J. Sedlet, I. R. Tasker, and P. -K. Tse, The Generic TRUEX Model, Volume Four-Operating Manual for the IBM-PC Version, ANL-89/38, Argonne National Laboratory, Argonne, IL (December, 1989) 
WSRC-TR-98-00376, Rev 0

APPENDIX 
Table IV. Uranium Distribution Data from DP-53 Table VIII and Comparison with SEPHIS Results.

\begin{tabular}{|c|c|c|c|c|c|c|c|c|c|}
\hline $\begin{array}{c}\text { TBP } \\
\text { Volume } \%\end{array}$ & $\begin{array}{l}\mathrm{T} \\
\mathrm{C}\end{array}$ & $\begin{array}{l}\mathrm{Ha} \\
\mathrm{M}\end{array}$ & $\begin{array}{l}\text { Ua } \\
\mathrm{M}\end{array}$ & $\begin{array}{l}\text { Uo } \\
\mathrm{M}\end{array}$ & $\begin{array}{c}\text { Doa } \\
\text { DP-53 }\end{array}$ & $\begin{array}{l}\mathrm{Ua} \\
\mathrm{g} / \mathrm{l}\end{array}$ & $\begin{array}{l}\text { Doa } \\
\text { calc. }\end{array}$ & $\begin{array}{c}\text { Doa } \\
\text { Sephis }\end{array}$ & $\begin{array}{l}\text { Error } \\
\text { Sephis }\end{array}$ \\
\hline 2.5 & 1.7 & 3.21 & 0.0029 & 0.0073 & 2.51 & 0.682 & 2.517 & 2.494 & $1 \%$ \\
\hline 2.5 & 1.4 & 3.99 & 0.00239 & 0.0078 & 3.25 & 0.562 & 3.264 & 2.862 & $12 \%$ \\
\hline 2.5 & 1.3 & 4.81 & 0.00223 & 0.008 & 3.57 & 0.524 & 3.587 & 2.821 & $21 \%$ \\
\hline 2.5 & 25.0 & 0.93 & 0.0058 & 0.00087 & 0.151 & 1.363 & 0.150 & 0.166 & $-10 \%$ \\
\hline 2.5 & 25.0 & 1.23 & 0.00458 & 0.00112 & 0.245 & 1.076 & 0.245 & 0.285 & $-16 \%$ \\
\hline 2.5 & 25.0 & 1.53 & 0.00354 & 0.00133 & 0.375 & 0.832 & 0.376 & 0.448 & $-20 \%$ \\
\hline 2.5 & 25.0 & 2.33 & 0.003 & 0.00239 & 0.8 & 0.705 & 0.797 & 1.027 & $-28 \%$ \\
\hline 2.5 & 25.3 & 3.15 & 0.00321 & 0.00349 & $(1.09)$ & 0.754 & 1.087 & 1.515 & $-39 \%$ \\
\hline 2.5 & 25.3 & 3.91 & 0.00278 & 0.00373 & $(1.38)$ & 0.653 & 1.342 & 1.767 & $-28 \%$ \\
\hline 2.5 & 25.3 & 4.72 & 0.00264 & 0.00377 & $(1.45)$ & 0.620 & 1.428 & 1.770 & $-22 \%$ \\
\hline 5.0 & 25.0 & 0.60 & 0.00458 & 0.00112 & 0.245 & 1.076 & 0.245 & 0.241 & $1 \%$ \\
\hline 5.0 & 25.0 & 0.92 & 0.00401 & 0.00206 & 0.513 & 0.942 & 0.514 & 0.495 & $3 \%$ \\
\hline 5.0 & 25.0 & 1.23 & 0.00379 & 0.0032 & 0.84 & 0.891 & 0.844 & 0.835 & $1 \%$ \\
\hline 5.0 & 25.0 & 1.53 & 0.00289 & 0.00365 & 1.26 & 0.679 & 1.263 & 1.271 & $-1 \%$ \\
\hline 5.0 & 25.2 & 2.18 & 0.00325 & 0.00693 & $(2.14)$ & 0.764 & 2.132 & 2.319 & $-8 \%$ \\
\hline 5.0 & 25.2 & 2.81 & 0.00256 & 0.00759 & $(2.97)$ & 0.602 & 2.965 & 3.367 & $-13 \%$ \\
\hline 5.0 & 25.2 & 4.69 & 0.00193 & 0.0083 & $(4.14)$ & 0.454 & 4.301 & 4.264 & $-3 \%$ \\
\hline 5.0 & 25.2 & 6.28 & 0.00214 & 0.008 & $(3.77)$ & 0.503 & 3.738 & 3.423 & $9 \%$ \\
\hline 5.0 & 45.9 & 0.60 & 0.00608 & 0.00082 & 0.135 & 1.429 & 0.135 & 0.142 & $-6 \%$ \\
\hline 5.0 & 45.9 & 0.90 & 0.00437 & 0.0011 & 0.252 & 1.027 & 0.252 & 0.284 & $-13 \%$ \\
\hline 5.0 & 45.9 & 1.16 & 0.00317 & 0.0014 & 0.442 & 0.745 & 0.442 & 0.456 & $-3 \%$ \\
\hline 5.0 & 45.9 & 1.46 & 0.00275 & 0.00186 & 0.667 & 0.646 & 0.676 & 0.715 & $-7 \%$ \\
\hline 5.0 & 45.9 & 2.13 & 0.00297 & 0.00361 & 1.21 & 0.698 & 1.215 & 1.463 & $-21 \%$ \\
\hline 5.0 & 45.9 & 2.71 & 0.00236 & 0.00381 & 1.61 & 0.555 & 1.614 & 2.175 & $-35 \%$ \\
\hline 5.0 & 45.9 & 4.69 & 0.00327 & 0.00691 & 2.09 & 0.768 & 2.113 & 2.769 & $-32 \%$ \\
\hline 5.0 & 45.9 & 6.28 & 0.0037 & 0.00648 & 1.73 & 0.870 & 1.751 & 2.242 & $-30 \%$ \\
\hline 5.0 & 25.0 & 3.48 & 0.00285 & 0.0099 & 3.46 & 0.670 & 3.474 & 3.914 & $-13 \%$ \\
\hline 5.0 & 45.9 & 3.48 & 0.00263 & 0.00505 & 1.92 & 0.618 & 1.920 & 2.748 & $-43 \%$ \\
\hline 5.0 & 70.0 & 3.48 & 0.00256 & 0.00254 & 0.99 & 0.602 & 0.992 & 1.856 & $-87 \%$ \\
\hline 7.5 & 25.1 & 0.60 & 0.00401 & 0.00206 & $(0.52)$ & 0.942 & 0.514 & 0.461 & $10 \%$ \\
\hline 7.5 & 25.1 & 0.91 & 0.00337 & 0.00341 & $(1.01)$ & 0.792 & 1.012 & 0.906 & $10 \%$ \\
\hline 7.5 & 25.1 & 1.25 & 0.00382 & 0.00636 & $(1.67)$ & 0.898 & 1.665 & 1.544 & $8 \%$ \\
\hline 7.5 & 25.1 & 1.56 & 0.003 & 0.0072 & $(2.39)$ & 0.705 & 2.400 & 2.299 & $4 \%$ \\
\hline 7.5 & 25.1 & 2.33 & 0.00194 & 0.0082 & $(4.25)$ & 0.456 & 4.227 & 4.548 & $-7 \%$ \\
\hline 7.5 & 25.1 & 3.10 & 0.00144 & 0.0087 & $(6.04)$ & 0.338 & 6.042 & 6.477 & $-7 \%$ \\
\hline 7.5 & 25.1 & 3.86 & 0.0012 & 0.009 & $(7.40)$ & 0.282 & 7.500 & 7.385 & $0 \%$ \\
\hline 7.5 & 25.1 & 4.65 & 0.00112 & 0.0091 & $(8.00)$ & 0.263 & 8.125 & 7.325 & $8 \%$ \\
\hline 7.5 & 45.9 & 0.52 & 0.0234 & 0.00544 & 0.232 & 5.499 & 0.232 & 0.229 & $1 \%$ \\
\hline 7.5 & 45.9 & 0.78 & 0.0169 & 0.0071 & 0.422 & 3.972 & 0.420 & 0.412 & $2 \%$ \\
\hline 7.5 & 45.9 & 1.03 & 0.009 & 0.00619 & 0.69 & 2.115 & 0.688 & 0.656 & $5 \%$ \\
\hline 7.5 & 45.9 & 1.53 & 0.00674 & 0.0086 & 1.28 & 1.584 & 1.276 & 1.314 & $-3 \%$ \\
\hline 7.5 & 45.9 & 2.02 & 0.00353 & 0.00682 & 1.93 & 0.830 & 1.932 & 2.237 & $-16 \%$ \\
\hline 7.5 & 45.9 & 2.78 & 0.0013 & 0.00386 & 2.97 & 0.306 & 2.969 & 3.861 & $-30 \%$ \\
\hline 7.5 & 45.9 & 3.42 & 0.00113 & 0.00398 & 3.52 & 0.266 & 3.522 & 4.746 & $-35 \%$ \\
\hline 7.5 & 45.9 & 4.44 & 0.00105 & 0.00397 & 3.78 & 0.247 & 3.781 & 5.095 & $-35 \%$ \\
\hline 10.0 & 25.0 & 3.48 & 0.00118 & 0.0115 & 9.78 & 0.277 & 9.746 & 9.953 & $-2 \%$ \\
\hline 10.0 & 45.9 & 3.48 & 0.002 & 0.0107 & 5.36 & 0.470 & 5.350 & 6.340 & $-18 \%$ \\
\hline 10.0 & 70.0 & 3.48 & 0.00398 & 0.01165 & 2.76 & 0.935 & 2.927 & 3.943 & $-43 \%$ \\
\hline 10.0 & 25.0 & 1.00 & 0.00262 & 0.00505 & 1.93 & 0.616 & 1.927 & 1.636 & $15 \%$ \\
\hline 10.0 & 45.9 & 1.02 & 0.0028 & 0.00333 & 1.19 & 0.658 & 1.189 & 1.017 & $15 \%$ \\
\hline 10.0 & 70.0 & 1.03 & 0.00288 & 0.00197 & 0.684 & 0.677 & 0.684 & 0.618 & $10 \%$ \\
\hline 10.0 & 45.9 & 0.55 & 0.0032 & 0.0014 & 0.436 & 0.752 & 0.438 & 0.373 & $14 \%$ \\
\hline 10.0 & 45.9 & 0.89 & 0.00352 & 0.00333 & 0.946 & 0.827 & 0.946 & 0.807 & $15 \%$ \\
\hline 10.0 & 45.9 & 2.48 & 0.00336 & 0.0136 & 4.02 & 0.790 & 4.048 & 4.317 & $-7 \%$ \\
\hline 10.0 & 45.9 & 4.66 & 0.00261 & 0.0151 & 5.72 & 0.613 & 5.785 & 6.352 & $-11 \%$ \\
\hline
\end{tabular}


Table V. Uranium Distribution Data from DP-1384 Tables 1 \& 4 for $23 \mathrm{C}$ and Comparison with SEPHIS Results.

\begin{tabular}{|c|c|c|c|c|c|c|c|c|c|c|}
\hline $\begin{array}{c}\text { HNO3a } \\
M\end{array}$ & $\begin{array}{l}\mathrm{Ua} \\
\mathrm{M}\end{array}$ & $\begin{array}{l}\text { rho } \\
\mathrm{g} / \mathrm{ml}\end{array}$ & $\begin{array}{c}\text { ANN } \\
\text { M }\end{array}$ & $\begin{array}{c}\text { HNO3o } \\
M\end{array}$ & $\begin{array}{l}\text { Uo } \\
\text { M }\end{array}$ & $\begin{array}{l}\mathrm{Ua} \\
\mathrm{g} / \mathrm{l}\end{array}$ & $\begin{array}{c}\text { Doa } \\
\text { HNO3 }\end{array}$ & $\begin{array}{c}\text { Doa } \\
\text { U }\end{array}$ & $\begin{array}{c}\text { Sephis Error } \\
\text { HNO3 }\end{array}$ & $\begin{array}{c}\text { Sephis Error } \\
\text { U }\end{array}$ \\
\hline 0.114 & 0.9100 & 1.29 & 0 & 0.004 & 0.115 & 213.85 & 0.035 & 0.126 & $76 \%$ & $-6 \%$ \\
\hline 0.108 & 0.4200 & 1.14 & 0 & 0.003 & 0.077 & 98.70 & 0.028 & 0.183 & $52 \%$ & $-10 \%$ \\
\hline 0.105 & 0.2100 & 1.07 & 0 & 0.002 & 0.036 & 49.35 & 0.019 & 0.171 & $21 \%$ & $-18 \%$ \\
\hline 0.103 & 0.0730 & 1.03 & 0 & 0.001 & 0.0063 & 17.16 & 0.010 & 0.086 & $-20 \%$ & $-25 \%$ \\
\hline 0.100 & 0.0370 & 1.01 & 0 & 0.001 & 0.0021 & 8.695 & 0.010 & 0.057 & $9 \%$ & $-17 \%$ \\
\hline 0.100 & 0.0197 & 1.01 & 0 & $(0.001)$ & 0.00074 & 4.630 & $(0.010)$ & 0.038 & $177 \%$ & $-27 \%$ \\
\hline 0.100 & 0.0098 & 1.00 & 0 & $(0.001)$ & 0.00031 & 2.303 & $(0.010)$ & 0.032 & $168 \%$ & $-20 \%$ \\
\hline 0.100 & 0.0050 & 1.00 & 0 & $(0.001)$ & 0.00017 & 1.175 & $(0.010)$ & 0.034 & $164 \%$ & $2 \%$ \\
\hline 0.11 & 0.000211 & & 0 & $(0.001)$ & $5.3 \mathrm{E}-06$ & 0.050 & $(0.009)$ & 0.025 & $171 \%$ & $-34 \%$ \\
\hline 0.52 & 0.87 & 1.30 & 0 & 0.006 & 0.118 & 204.45 & 0.012 & 0.136 & $30 \%$ & $-5 \%$ \\
\hline 0.51 & 0.68 & 1.24 & 0 & 0.006 & 0.111 & 159.80 & 0.012 & 0.163 & $19 \%$ & $-5 \%$ \\
\hline 0.51 & 0.56 & 1.19 & 0 & 0.006 & 0.101 & 131.60 & 0.012 & 0.180 & $8 \%$ & $-9 \%$ \\
\hline 0.51 & 0.41 & 1.15 & 0 & 0.007 & 0.091 & 96.35 & 0.014 & 0.222 & $6 \%$ & $-7 \%$ \\
\hline 0.50 & 0.27 & 1.10 & 0 & 0.008 & 0.071 & 63.45 & 0.016 & 0.263 & $2 \%$ & $-9 \%$ \\
\hline 0.50 & 0.192 & 1.08 & 0 & 0.008 & 0.056 & 45.12 & 0.016 & 0.292 & $-10 \%$ & $-10 \%$ \\
\hline 0.50 & 0.114 & 1.05 & 0 & 0.009 & 0.036 & 26.79 & 0.018 & 0.316 & $-9 \%$ & $-13 \%$ \\
\hline 0.50 & 0.059 & 1.03 & 0 & 0.009 & 0.022 & 13.87 & 0.018 & 0.373 & $-16 \%$ & $0 \%$ \\
\hline 0.50 & 0.045 & 1.03 & 0 & 0.009 & 0.0150 & 10.58 & 0.018 & 0.333 & $-18 \%$ & $-13 \%$ \\
\hline 0.50 & 0.0150 & 1.02 & 0 & 0.009 & 0.0050 & 3.525 & 0.018 & 0.333 & $-20 \%$ & $-11 \%$ \\
\hline 0.50 & 0.0076 & 1.02 & 0 & 0.009 & 0.0023 & 1.786 & 0.018 & 0.303 & $-20 \%$ & $-22 \%$ \\
\hline 0.50 & 0.0046 & 1.02 & 0 & 0.009 & 0.00141 & 1.081 & 0.018 & 0.307 & $-20 \%$ & $-20 \%$ \\
\hline 1.01 & 0.55 & 1.21 & 0 & 0.011 & 0.110 & 129.25 & 0.011 & 0.200 & $7 \%$ & $-5 \%$ \\
\hline 1.04 & 0.41 & 1.16 & 0 & 0.012 & 0.102 & 96.35 & 0.012 & 0.249 & $-3 \%$ & $-6 \%$ \\
\hline 1.03 & 0.26 & 1.12 & 0 & 0.014 & 0.087 & 61.10 & 0.014 & 0.335 & $-11 \%$ & $-7 \%$ \\
\hline 1.04 & 0.180 & 1.09 & 0 & 0.017 & 0.075 & 42.300 & 0.016 & 0.417 & $-9 \%$ & $-8 \%$ \\
\hline 1.02 & 0.095 & 1.06 & 0 & 0.020 & 0.055 & 22.325 & 0.020 & 0.579 & $-15 \%$ & $-6 \%$ \\
\hline 1.00 & 0.044 & 1.05 & 0 & 0.023 & 0.036 & 10.340 & 0.023 & 0.818 & $-18 \%$ & $3 \%$ \\
\hline 1.03 & 0.033 & 1.04 & 0 & 0.026 & 0.027 & 7.755 & 0.025 & 0.818 & $-15 \%$ & $-8 \%$ \\
\hline 1.03 & 0.021 & 1.04 & 0 & 0.029 & 0.0191 & 4.935 & 0.028 & 0.910 & $-10 \%$ & $-8 \%$ \\
\hline 1.04 & 0.0101 & 1.03 & 0 & 0.030 & 0.0105 & 2.374 & 0.029 & 1.040 & $-16 \%$ & $-7 \%$ \\
\hline 1.01 & 0.0044 & 1.03 & 0 & 0.032 & 0.0055 & 1.034 & 0.032 & 1.250 & $-8 \%$ & $10 \%$ \\
\hline 0.95 & 0.00011 & & 0 & 0.03 & $9.90 \mathrm{E}-0.5$ & 0.026 & 0.032 & 0.900 & $-8 \%$ & $-18 \%$ \\
\hline 2.03 & 0.69 & 1.28 & 0 & 0.015 & 0.120 & 162.15 & 0.007 & 0.174 & $-9 \%$ & $-3 \%$ \\
\hline 2.02 & 0.54 & 1.24 & 0 & 0.018 & 0.116 & 126.90 & 0.009 & 0.215 & $-3 \%$ & $-4 \%$ \\
\hline 2 & 0.40 & 1.19 & 0 & 0.020 & 0.112 & 94.00 & 0.010 & 0.280 & $-10 \%$ & $-3 \%$ \\
\hline 2.04 & 0.24 & 1.15 & 0 & 0.026 & 0.104 & 56.40 & 0.013 & 0.433 & $-9 \%$ & $-2 \%$ \\
\hline 2.02 & 0.076 & 1.09 & 0 & 0.042 & 0.084 & 17.86 & 0.021 & 1.105 & $-10 \%$ & $6 \%$ \\
\hline 1.96 & 0.030 & 1.08 & 0 & 0.058 & 0.051 & 7.050 & 0.030 & 1.700 & $-7 \%$ & $-4 \%$ \\
\hline 2.02 & 0.020 & 1.07 & 0 & 0.064 & 0.040 & 4.700 & 0.032 & 2.000 & $-11 \%$ & $-10 \%$ \\
\hline 1.98 & 0.0119 & 1.07 & 0 & 0.074 & 0.028 & 2.797 & 0.037 & 2.353 & $-6 \%$ & $-12 \%$ \\
\hline 2.16 & 0.0055 & 1.07 & 0 & 0.096 & 0.0152 & 1.293 & 0.044 & 2.764 & $-2 \%$ & $-31 \%$ \\
\hline 2.11 & 0.0025 & 1.06 & 0 & 0.098 & 0.0079 & 0.588 & 0.046 & 3.160 & $-5 \%$ & $-27 \%$ \\
\hline 2.16 & $4.80 \mathrm{E}-05$ & & 0 & 0.105 & $1.63 \mathrm{E}-04$ & 0.011 & 0.049 & 3.396 & $-9 \%$ & $-40 \%$ \\
\hline 2.85 & 0.54 & 1.26 & 0 & 0.022 & 0.118 & 126.90 & 0.008 & 0.219 & $-12 \%$ & $-3 \%$ \\
\hline 2.91 & 0.38 & 1.22 & 0 & 0.028 & 0.114 & 89.30 & 0.010 & 0.300 & $-7 \%$ & $-2 \%$ \\
\hline 3.00 & 0.24 & 1.18 & 0 & 0.035 & 0.108 & 56.40 & 0.012 & 0.450 & $-10 \%$ & $-2 \%$ \\
\hline 3.10 & 0.148 & 1.15 & 0 & 0.042 & 0.099 & 34.78 & 0.014 & 0.669 & $-17 \%$ & $-3 \%$ \\
\hline 3.10 & 0.067 & 1.12 & 0 & 0.062 & 0.088 & 15.75 & 0.020 & 1.313 & $-11 \%$ & $2 \%$ \\
\hline 3.10 & 0.024 & 1.12 & 0 & 0.092 & 0.060 & 5.640 & 0.030 & 2.500 & $-8 \%$ & $-4 \%$ \\
\hline 3.00 & 0.0143 & 1.10 & 0 & 0.106 & 0.045 & 3.361 & 0.035 & 3.147 & $-7 \%$ & $-8 \%$ \\
\hline 3.10 & 0.0083 & 1.10 & 0 & 0.122 & 0.032 & 1.951 & 0.039 & 3.855 & $-8 \%$ & $-14 \%$ \\
\hline 3.00 & 0.0033 & 1.10 & 0 & 0.142 & 0.0158 & 0.776 & 0.047 & 4.788 & $-5 \%$ & $-20 \%$ \\
\hline 3.10 & 0.00162 & 1.10 & 0 & 0.152 & 0.0087 & 0.381 & 0.049 & 5.370 & $-9 \%$ & $-24 \%$ \\
\hline 2.90 & $3.60 \mathrm{E}-05$ & & 0 & 0.150 & $1.87 \mathrm{E}-04$ & 0.008 & 0.052 & 5.194 & $-11 \%$ & $-39 \%$ \\
\hline
\end{tabular}


Table V. Uranium Distribution Data from DP-1384 Tables $1 \& 4$ for $23^{\circ} \mathrm{C}$ and Comparison with SEPHIS Results (continued).

\begin{tabular}{|c|c|c|c|c|c|c|c|c|c|c|}
\hline $\begin{array}{c}\text { HNO3a } \\
M\end{array}$ & $\begin{array}{l}\mathrm{Ua} \\
\mathrm{M}\end{array}$ & $\begin{array}{l}\text { rho } \\
\mathrm{g} / \mathrm{ml}\end{array}$ & $\begin{array}{c}\text { ANN } \\
M\end{array}$ & $\begin{array}{c}\text { HNO3o } \\
\text { M }\end{array}$ & $\begin{array}{l}\text { Uo } \\
\text { M }\end{array}$ & $\begin{array}{l}\mathrm{Ua} \\
\mathrm{g} /\end{array}$ & $\begin{array}{c}\text { Doa } \\
\text { HNO3 }\end{array}$ & $\begin{array}{c}\text { Doa } \\
\mathrm{U}\end{array}$ & $\begin{array}{c}\text { Sephis Error } \\
\text { HNO3 }\end{array}$ & $\begin{array}{c}\text { Sephis Error } \\
U\end{array}$ \\
\hline 4.20 & 0.39 & 1.26 & 0 & 0.032 & 0.109 & 91.65 & 0.008 & 0.279 & $-22 \%$ & $-6 \%$ \\
\hline 4.20 & 0.24 & 1.21 & 0 & 0.040 & 0.103 & 56.40 & 0.010 & 0.429 & $-23 \%$ & $-6 \%$ \\
\hline 4.20 & 0.152 & 1.18 & 0 & 0.050 & 0.097 & 35.72 & 0.012 & 0.638 & $-22 \%$ & $-6 \%$ \\
\hline 4.10 & 0.067 & 1.16 & 0 & 0.072 & 0.082 & 15.75 & 0.018 & 1.224 & $-17 \%$ & $-7 \%$ \\
\hline 4.10 & 0.021 & 1.14 & 0 & 0.110 & 0.058 & 4.935 & 0.027 & 2.762 & $-16 \%$ & $-5 \%$ \\
\hline 4.10 & 0.0132 & 1.14 & 0 & 0.125 & 0.047 & 3.102 & 0.030 & 3.561 & $-17 \%$ & $-6 \%$ \\
\hline 4.10 & 0.0070 & 1.13 & 0 & 0.150 & 0.032 & 1.645 & 0.037 & 4.571 & $-13 \%$ & $-10 \%$ \\
\hline 4.10 & 0.0030 & 1.13 & 0 & 0.170 & 0.018 & 0.705 & 0.041 & 6.000 & $-15 \%$ & $-10 \%$ \\
\hline 3.8 & $2.70 \mathrm{E}-05$ & & 0 & 0.200 & $1.90 \mathrm{E}-04$ & 0.006 & 0.053 & 7.037 & $-7 \%$ & $-24 \%$ \\
\hline 4.50 & 0.39 & 1.27 & 0 & 0.040 & 0.116 & 91.65 & 0.009 & 0.297 & $-3 \%$ & $1 \%$ \\
\hline 4.40 & 0.147 & 1.19 & 0 & 0.060 & 0.103 & 34.55 & 0.014 & 0.701 & $-6 \%$ & $2 \%$ \\
\hline 4.30 & 0.0193 & 1.15 & 0 & 0.130 & 0.059 & 4.536 & 0.030 & 3.057 & $-4 \%$ & $1 \%$ \\
\hline 4.40 & 0.0066 & 1.14 & 0 & 0.160 & 0.036 & 1.551 & 0.036 & 5.455 & $-12 \%$ & $6 \%$ \\
\hline 4.40 & 0.0028 & 1.14 & 0 & 0.185 & 0.0180 & 0.658 & 0.042 & 6.429 & $-11 \%$ & $-3 \%$ \\
\hline 4.5 & $2.40 \mathrm{E}-05$ & & 0 & 0.22 & $1.86 \mathrm{E}-04$ & 0.006 & 0.049 & 7.750 & $-8 \%$ & $-12 \%$ \\
\hline 5.30 & 0.100 & 1.27 & 0.51 & 0.08 & 0.094 & 23.50 & 0.015 & 0.940 & & \\
\hline 4.30 & 0.096 & 1.24 & 0.56 & 0.07 & 0.096 & 22.56 & 0.016 & 1.000 & & \\
\hline 3.20 & 0.093 & 1.21 & 0.56 & 0.06 & 0.099 & 21.86 & 0.019 & 1.065 & & \\
\hline 2.10 & 0.093 & 1.18 & 0.56 & 0.04 & 0.097 & 21.86 & 0.019 & 1.043 & $\therefore$ & \\
\hline 1.08 & 0.099 & 1.14 & 0.54 & 0.02 & 0.093 & 23.27 & 0.019 & 0.939 & & \\
\hline 0.55 & 0.104 & 1.13 & 0.55 & 0.01 & 0.088 & 24.44 & 0.018 & 0.846 & & \\
\hline 3.80 & 0.094 & 1.30 & 1.06 & 0.07 & 0.101 & 22.09 & 0.018 & 1.074 & & \\
\hline 2.70 & 0.090 & 1.27 & 1.05 & 0.05 & 0.107 & 21.15 & 0.019 & 1.189 & & \\
\hline 1.61 & 0.086 & 1.24 & 1.07 & 0.04 & 0.110 & 20.21 & 0.025 & 1.279 & & \\
\hline 0.57 & 0.087 & 1.20 & 1.12 & 0.02 & 0.111 & 20.45 & 0.035 & 1.276 & & \\
\hline 2.20 & 0.088 & 1.32 & 1.62 & 0.05 & 0.109 & 20.68 & 0.023 & 1.239 & & \\
\hline 1.16 & 0.081 & 1.29 & 1.61 & 0.03 & 0.114 & 19.04 & 0.026 & 1.407 & & \\
\hline 0.62 & 0.078 & 1.28 & 1.62 & 0.02 & 0.122 & 18.33 & 0.032 & 1.564 & & \\
\hline 1.01 & 0.000076 & 1.26 & 1.61 & 0.19 & 0.0057 & 0.018 & 0.188 & 75.000 & & \\
\hline 0.97 & 0.000147 & 1.26 & 1.62 & 0.18 & 0.0104 & 0.035 & 0.186 & 70.748 & & \\
\hline 1.04 & 0.000840 & 1.27 & 1.62 & 0.15 & 0.039 & 0.197 & 0.144 & 46.429 & & \\
\hline 1.07 & 0.00181 & 1.27 & 1.61 & 0.12 & 0.060 & 0.425 & 0.112 & 33.149 & & \\
\hline 1.10 & 0.0044 & 1.27 & 1.60 & 0.09 & 0.074 & 1.034 & 0.082 & 16.818 & & \\
\hline 1.13 & 0.0095 & 1.27 & 1.62 & 0.07 & 0.091 & 2.233 & 0.062 & 9.579 & & \\
\hline 1.11 & 0.038 & 1.28 & 1.60 & 0.04 & 0.125 & 8.930 & 0.036 & 3.289 & & \\
\hline 0.64 & 0.075 & 1.35 & 2.10 & 0.02 & 0.125 & 17.63 & 0.031 & 1.667 & & \\
\hline
\end{tabular}


Table VI. Uranium Distribution Data from DP-1384 Tables $2 \& 5$ for $45^{\circ} \mathrm{C}$ and Comparison with SEPHIS Results.

\begin{tabular}{|c|c|c|c|c|c|c|c|c|c|c|}
\hline $\begin{array}{c}\text { HNO3a } \\
M\end{array}$ & $\begin{array}{l}\mathrm{Ua} \\
\mathrm{M}\end{array}$ & $\begin{array}{l}\text { rho } \\
\mathrm{g} / \mathrm{ml}\end{array}$ & $\begin{array}{c}\text { ANN } \\
\text { M }\end{array}$ & $\begin{array}{c}\text { HNO3o } \\
\text { M }\end{array}$ & $\begin{array}{l}\text { Uo } \\
\text { M }\end{array}$ & $\begin{array}{l}\mathrm{Ua} \\
\mathrm{g} / \mathrm{l}\end{array}$ & $\begin{array}{c}\text { Doa } \\
\text { HNO3 }\end{array}$ & $\begin{array}{c}\text { Doa } \\
\text { U }\end{array}$ & $\begin{array}{c}\text { Sephis Error } \\
\text { HNO3 }\end{array}$ & $\begin{array}{c}\text { Sephis Error } \\
\text { U }\end{array}$ \\
\hline 0.116 & 0.84 & 1.28 & 0 & 0.0030 & 0.1090 & 197.40 & 0.026 & 0.130 & $59 \%$ & $-4 \%$ \\
\hline 0.106 & 0.42 & 1.14 & 0 & 0.0020 & 0.0670 & 98.70 & 0.019 & 0.160 & $18 \%$ & $-8 \%$ \\
\hline 0.105 & 0.22 & 1.07 & 0 & 0.0020 & 0.0260 & 51.70 & 0.019 & 0.118 & $15 \%$ & $-25 \%$ \\
\hline 0.104 & 0.072 & 1.02 & 0 & 0.0010 & 0.0034 & $16.92^{\circ}$ & 0.010 & 0.047 & $-15 \%$ & $-34 \%$ \\
\hline 0.101 & 0.038 & 1.01 & 0 & 0.0020 & 0.001180 & 8.930 & 0.020 & 0.031 & $56 \%$ & $-24 \%$ \\
\hline 0.100 & 0.0189 & 1.01 & 0 & & 0.000460 & 4.442 & 0.000 & 0.024 & & $-8 \%$ \\
\hline 0.101 & 0.0091 & 1.00 & 0 & & 0.000190 & 2.139 & 0.000 & 0.021 & & $-1 \%$ \\
\hline 0.096 & 0.0048 & 1.00 & 0 & & 0.000110 & 1.128 & 0.000 & 0.023 & & $24 \%$ \\
\hline 0.520 & 0.71 & 1.24 & 0 & 0.0060 & 0.1060 & 166.85 & 0.012 & 0.149 & $2 \%$ & $-6 \%$ \\
\hline 0.500 & 0.55 & 1.19 & 0 & 0.0080 & 0.0930 & 129.25 & 0.016 & 0.169 & $17 \%$ & $-9 \%$ \\
\hline 0.500 & 0.42 & 1.15 & 0 & 0.0090 & 0.0840 & 98.70 & 0.018 & 0.200 & $15 \%$ & $-5 \%$ \\
\hline 0.500 & 0.28 & 1.11 & 0 & 0.0090 & 0.0600 & 65.80 & 0.018 & 0.214 & $1 \%$ & $-11 \%$ \\
\hline 0.500 & 0.20 & 1.08 & 0 & 0.0090 & 0.0440 & 47.00 & 0.018 & 0.220 & $-8 \%$ & $-14 \%$ \\
\hline 0.500 & 0.12 & 1.06 & 0 & 0.0090 & 0.0240 & 28.20 & 0.018 & 0.200 & $-15 \%$ & $-27 \%$ \\
\hline 0.490 & 0.065 & 1.03 & 0 & 0.0120 & 0.0153 & 15.28 & 0.024 & 0.235 & $15 \%$ & $-1 \%$ \\
\hline 0.490 & 0.050 & 1.03 & 0 & 0.0100 & 0.0118 & 11.75 & 0.020 & 0.236 & $-2 \%$ & $2 \%$ \\
\hline 0.500 & 0.0172 & 1.02 & 0 & 0.0100 & 0.0033 & 4.042 & 0.020 & 0.192 & $-2 \%$ & $-13 \%$ \\
\hline 0.510 & 0.0084 & 1.02 & 0 & 0.0100 & 0.0016 & 1.974 & 0.020 & 0.193 & $-5 \%$ & $-13 \%$ \\
\hline 0.500 & 0.005 & 1.02 & 0 & 0.0090 & 0.0010 & 1.175 & 0.018 & 0.192 & $-12 \%$ & $-9 \%$ \\
\hline 1.030 & 0.70 & 1.26 & 0 & 0.0140 & 0.1090 & 164.50 & 0.014 & 0.156 & $22 \%$ & $-7 \%$ \\
\hline 1.030 & 0.55 & 1.21 & 0 & 0.0160 & 0.1010 & 129.25 & 0.016 & 0.184 & $21 \%$ & $-9 \%$ \\
\hline 1.030 & 0.42 & 1.17 & 0 & 0.0170 & 0.0930 & 98.70 & 0.017 & 0.221 & $14 \%$ & $-8 \%$ \\
\hline 1.030 & 0.28 & 1.12 & 0 & 0.0190 & 0.0770 & 65.80 & 0.018 & 0.275 & $6 \%$ & $-11 \%$ \\
\hline 1.030 & 0.185 & 1.09 & 0 & 0.0200 & 0.0630 & 43.48 & 0.019 & 0.341 & $-5 \%$ & $-9 \%$ \\
\hline 1.030 & 0.11 & 1.07 & 0 & 0.0230 & 0.0440 & 25.62 & 0.022 & 0.404 & $-8 \%$ & $-13 \%$ \\
\hline 1.020 & 0.05 & 1.05 & 0 & 0.0260 & 0.0260 & 12.69 & 0.025 & 0.481 & $-9 \%$ & $-13 \%$ \\
\hline 1.010 & 0.0400 & 1.04 & 0 & 0.0260 & 0.0200 & 9.400 & 0.026 & 0.500 & $-12 \%$ & $-13 \%$ \\
\hline 1.02 & 0.026 & 1.04 & 0 & 0.027 & 0.0143 & 6.110 & 0.026 & 0.550 & $-15 \%$ & $-10 \%$ \\
\hline 1.02 & 0.0125 & 1.04 & 0 & 0.028 & 0.0074 & 2.938 & 0.027 & 0.592 & $-16 \%$ & $-9 \%$ \\
\hline 1.02 & 0.0062 & 1.03 & 0 & 0.03 & 0.0038 & 1.457 & 0.029 & 0.613 & $-11 \%$ & $-9 \%$ \\
\hline 1.04 & 0.0037 & 1.03 & 0 & 0.03 & .0 .0022 & 0.870 & 0.029 & 0.595 & $-16 \%$ & $-18 \%$ \\
\hline 2.04 & 0.69 & 1.29 & 0 & 0.023 & 0.112 & 162.15 & 0.011 & 0.162 & $13 \%$ & $-8 \%$ \\
\hline 2.03 & 0.54 & 1.24 & 0 & 0.026 & 0.11 & 126.90 & 0.013 & 0.204 & $12 \%$ & $-6 \%$ \\
\hline 2.02 & 0.40 & 1.2 & 0 & 0.028 & 0.104 & 94.00 & 0.014 & 0.260 & $5 \%$ & $-6 \%$ \\
\hline 2.02 & 0.26 & 1.15 & 0 & 0.036 & 0.09 & 61.10 & 0.018 & 0.346 & $9 \%$ & $-12 \%$ \\
\hline 2.03 & 0.166 & 1.12 & 0 & 0.04 & 0.081 & 39.01 & 0.020 & 0.488 & $0 \%$ & $-10 \%$ \\
\hline 2.00 & 0.087 & 1.09 & 0 & 0.049 & 0.063 & 20.45 & 0.025 & 0.724 & $-3 \%$ & $-12 \%$ \\
\hline 2.02 & 0.038 & 1.08 & 0 & 0.066 & 0.044 & 8.930 & 0.033 & 1.158 & $0 \%$ & $-9 \%$ \\
\hline 2.01 & 0.027 & 1.07 & 0 & 0.073 & 0.035 & 6.345 & 0.036 & 1.296 & $2 \%$ & $-12 \%$ \\
\hline 2.00 & 0.0169 & 1.07 & 0 & 0.078 & 0.023 & 3.972 & 0.039 & 1.361 & $0 \%$ & $-24 \%$ \\
\hline 2.00 & 0.0072 & 1.06 & 0 & 0.086 & 0.0125 & 1.692 & 0.043 & 1.736 & $-2 \%$ & $-18 \%$ \\
\hline 2.00 & 0.0033 & 1.06 & 0 & 0.089 & 0.0063 & 0.776 & 0.045 & 1.909 & $-4 \%$ & $-18 \%$ \\
\hline 2.00 & 0.00173 & 1.06 & 0 & 0.09 & 0.0032 & 0.407 & 0.045 & 1.850 & $-6 \%$ & $-27 \%$ \\
\hline 2.8 & 0.55 & 1.27 & 0 & 0.033 & 0.112 & 129.25 & 0.012 & 0.204 & $11 \%$ & $-5 \%$ \\
\hline 2.9 & 0.40 & 1.22 & 0 & 0.039 & 0.105 & 94.00 & 0.013 & 0.263 & $9 \%$ & $-7 \%$ \\
\hline 2.9 & 0.26 & 1.18 & 0 & 0.048 & 0.098 & 61.10 & 0.017 & 0.377 & $9 \%$ & $-7 \%$ \\
\hline 3.0 & 0.159 & 1.15 & 0 & 0.058 & 0.089 & 37.37 & 0.019 & 0.560 & $4 \%$ & $-8 \%$ \\
\hline 3.0 & 0.078 & 1.12 & 0 & 0.078 & 0.071 & 18.33 & 0.026 & 0.910 & $5 \%$ & $-12 \%$ \\
\hline 3.0 & 0.031 & 1.11 & 0 & 0.098 & 0.051 & 7.285 & 0.033 & 1.645 & $-4 \%$ & $-10 \%$ \\
\hline 3.0 & 0.021 & 1.1 & 0 & 0.118 & 0.038 & 4.935 & 0.039 & 1.810 & $4 \%$ & $-22 \%$ \\
\hline 3.0 & 0.0052 & 1.1 & 0 & 0.143 & 0.0158 & 1.222 & 0.048 & 3.038 & $-2 \%$ & $-17 \%$ \\
\hline 3.0 & 0.0025 & 1.1 & 0 & 0.154 & 0.0076 & 0.588 & 0.051 & 3.040 & $-1 \%$ & $-32 \%$ \\
\hline 3.0 & 0.00137 & 1.1 & 0 & 0.156 & 0.0038 & 0.322 & 0.052 & 2.774 & $-3 \%$ & $-54 \%$ \\
\hline
\end{tabular}


Table VI. Uranium Distribution Data from DP-1384 Tables $2 \& 5$ for $45^{\circ} \mathrm{C}$ and Comparison with SEPHIS Results (continued).

\begin{tabular}{|c|c|c|c|c|c|c|c|c|c|c|}
\hline $\begin{array}{c}\text { FNO3a } \\
\mathbf{M}\end{array}$ & $\begin{array}{l}\mathrm{Ua} \\
\mathrm{M}\end{array}$ & $\begin{array}{l}\text { tho } \\
\mathrm{g} / \mathrm{ml}\end{array}$ & $\begin{array}{c}\text { ANN } \\
M\end{array}$ & $\begin{array}{c}\text { HNO3o } \\
\text { M }\end{array}$ & $\begin{array}{l}\text { Uo } \\
\text { M }\end{array}$ & $\begin{array}{l}\text { Ua } \\
\mathrm{g} / \mathrm{l}\end{array}$ & $\begin{array}{c}\text { Doa } \\
\text { HNO3 }\end{array}$ & $\begin{array}{c}\text { Doa } \\
\text { U }\end{array}$ & $\begin{array}{c}\text { Sephis Error } \\
\text { HNO3 }\end{array}$ & $\begin{array}{c}\text { Sephis Error } \\
\text { U }\end{array}$ \\
\hline 4.2 & 0.39 & 1.26 & 0 & 0.048 & 0.105 & 91.65 & 0.011 & 0.269 & $1 \%$ & $-5 \%$ \\
\hline 4.2 & 0.25 & 1.21 & 0 & 0.057 & 0.1 & 58.75 & 0.014 & 0.400 & $-2 \%$ & $-4 \%$ \\
\hline 4.2 & 0.162 & 1.18 & 0 & 0.066 & 0.09 & 38.07 & 0.016 & 0.556 & $-7 \%$ & $-7 \%$ \\
\hline 4.1 & 0.075 & 1.16 & 0 & 0.093 & 0.074 & 17.63 & 0.023 & 0.987 & $-2 \%$ & $-9 \%$ \\
\hline 4.1 & 0.028 & 1.15 & 0 & 0.128 & 0.052 & 6.580 & 0.031 & 1.857 & $-4 \%$ & $-10 \%$ \\
\hline 4.1 & 0.0193 & 1.14 & 0 & 0.146 & 0.041 & 4.536 & 0.036 & 2.124 & $-1 \%$ & $-17 \%$ \\
\hline 4.1 & 0.0112 & 1.13 & 0 & 0.164 & 0.029 & 2.632 & 0.040 & 2.589 & $-2 \%$ & $-23 \%$ \\
\hline 4.1 & 0.0048 & 1.13 & 0 & 0.181 & 0.0156 & 1.128 & 0.044 & 3.250 & $-6 \%$ & $-28 \%$ \\
\hline 4 & 0.0022 & 1.13 & 0 & 0.198 & 0.0081 & 0.517 & 0.050 & 3.682 & $-3 \%$ & $-31 \%$ \\
\hline 4.0 & 0.00109 & 1.13 & 0 & 0.2 & 0.0042 & 0.256 & 0.050 & 3.853 & $-6 \%$ & $-34 \%$ \\
\hline 4.5 & 0.40 & 1.27 & 0 & 0.05 & 0.105 & 94.00 & 0.011 & 0.263 & $2 \%$ & $-5 \%$ \\
\hline 4.4 & 0.153 & 1.19 & 0 & 0.08 & 0.09 & 35.96 & 0.018 & 0.588 & $7 \%$ & $-5 \%$ \\
\hline 4.2 & 0.028 & 1.15 & 0 & 0.14 & 0.05 & 6.580 & 0.033 & 1.786 & $4 \%$ & $-14 \%$ \\
\hline 4.3 & 0.0108 & 1.14 & 0 & 0.18 & 0.029 & 2.538 & 0.042 & 2.685 & $4 \%$ & $-20 \%$ \\
\hline 4.2 & 0.0045 & 1.14 & 0 & 0.2 & 0.0148 & 1.058 & 0.048 & 3.289 & $2 \%$ & $-29 \%$ \\
\hline 4.2 & 0.0021 & 1.14 & 0 & 0.2 & 0.0077 & 0.494 & 0.048 & 3.667 & $-5 \%$ & $-32 \%$ \\
\hline 4.2 & 0.00105 & 1.14 & 0 & 0.2 & 0.0038 & 0.247 & 0.048 & 3.619 & $-9 \%$ & $-44 \%$ \\
\hline 5.20 & 0.110 & 1.28 & 0.51 & 0.101 & 0.080 & 25.85 & 0.019 & 0.727 & & \\
\hline 4.20 & 0.106 & 1.25 & 0.56 & 0.088 & 0.085 & 24.91 & 0.021 & 0.802 & - & \\
\hline 3.20 & 0.104 & 1.21 & 0.56 & 0.070 & 0.088 & 24.44 & 0.022 & 0.846 & - & \\
\hline 2.10 & 0.100 & 1.18 & 0.56 & 0.056 & 0.086 & 23.50 & 0.027 & 0.860 & & \\
\hline 1.06 & 0.107 & 1.15 & 0.54 & 0.029 & 0.086 & 25.15 & 0.027 & 0.804 & & \\
\hline 0.52 & 0.110 & 1.13 & 0.55 & 0.016 & 0.080 & 25.85 & 0.031 & 0.727 & & \\
\hline 3.70 & 0.102 & 1.30 & 1.06 & 0.082 & 0.090 & 23.97 & 0.022 & 0.882 & & \\
\hline 2.60 & 0.099 & 1.27 & 1.05 & 0.064 & 0.093 & 23.27 & 0.025 & 0.939 & & \\
\hline 1.66 & $0: 090$ & 1.24 & 1.07 & 0.045 & 0.096 & 21.15 & 0.027 & 1.067 & & \\
\hline 0.57 & 0.086 & 1.20 & 1.12 & 0.019 & 0.102 & 20.21 & 0.033 & 1.186 & & \\
\hline 2.20 & 0.091 & 1.33 & 1.62 & 0.058 & 0.100 & 21.39 & 0.026 & 1.099 & & \\
\hline 1.16 & 0.083 & 1.30 & 1.61 & 0.036 & 0.106 & 19.51 & 0.031 & 1.277 & & \\
\hline 0.63 & 0.077 & 1.28 & 1.62 & 0.021 & 0.109 & 18.10 & 0.033 & 1.416 & & \\
\hline 0.96 & 0.00013 & 1.26 & 1.61 & 0.20 & 0.0052 & 0.0306 & 0.208 & 40.000 & & \\
\hline 0.98 & 0.00025 & 1.26 & 1.62 & 0.19 & 0.0094 & 0.059 & 0.194 & 37.600 & & \\
\hline 1.05 & 0.00151 & 1.27 & 1.62 & 0.14 & 0.037 & 0.355 & 0.133 & 24.503 & . & \\
\hline 1.10 & 0.0035 & 1.27 & 1.61 & 0.12 & 0.055 & 0.823 & 0.109 & 15.714 & & \\
\hline 1.10 & 0.0073 & 1.27 & 1.60 & 0.09 & 0.069 & 1.716 & 0.082 & 9.452 & & \\
\hline 1.14 & 0.0109 & 1.27 & 1.62 & 0.07 & 0.078 & 2.562 & 0.061 & 7.156 & & \\
\hline 1.17 & 0.043 & 1.28 & 1.60 & 0.04 & 0.101 & 10.11 & 0.034 & 2.349 & & \\
\hline 0.66 & 0.073 & 1.35 & 2.10 & 0.026 & 0.114 & 17.16 & 0.039 & 1.562 & & \\
\hline
\end{tabular}


WSRC-TR-98-00376, Rev 0

Table VII. Uranium Distribution Data from DP-1384 Table 3 for $60^{\circ} \mathrm{C}$ and Comparison with SEPHIS Results.

\begin{tabular}{|c|c|c|c|c|c|c|c|c|c|c|c|}
\hline HNO3a & $\overline{\mathrm{Ua}}$ & rho & $\overline{\text { ANN }}$ & HNO3o & Uo & rho & $\mathrm{Ua}$ & Doa & Doa & \multicolumn{2}{|c|}{ Sephis Error Sephis Enor } \\
\hline M & $\mathbf{M}$ & $\mathrm{g} / \mathrm{ml}$ & $\mathbf{M}$ & M & M & $\mathrm{g} / \mathrm{ml}$ & $\mathrm{g} / 1$ & HNO3 & $\mathrm{U}$ & $\mathbf{H}$ & $\mathrm{U}$ \\
\hline 0.105 & 0.87 & 1.29 & 0 & 0.0038 & 0.101 & 0.81 & 204.5 & 0.036 & 0.116 & $67 \%$ & $-10 \%$ \\
\hline 0.105 & 0.44 & 1.14 & 0 & 0.0021 & 0.057 & 0.79 & 103.4 & 0.020 & 0.130 & $17 \%$ & $-18 \%$ \\
\hline 0.103 & 0.22 & 1.07 & 0 & 0.0011 & 0.021 & 0.78 & 51.7 & 0.011 & 0.095 & $-56 \%$ & $-23 \%$ \\
\hline 0.103 & 0.076 & 1.02 & 0 & 0.0005 & 0.0026 & 0.77 & 17.86 & 0.005 & 0.034 & $-134 \%$ & $-38 \%$ \\
\hline 0.104 & 0.039 & 1.01 & 0 & 0.0004 & 0.000690 & 0.77 & 9.165 & 0.004 & 0.018 & $-104 \%$ & $-61 \%$ \\
\hline 0.100 & 0.020 & 1.01 & 0 & 0.0005 & 0.000240 & 0.77 & 4.700 & 0.005 & 0.012 & $-27 \%$ & $-58 \%$ \\
\hline 0.102 & 0.0095 & 1.00 & 0 & 0.0008 & 0.000080 & 0.77 & 2.233 & 0.008 & 0.008 & $22 \%$ & $-80 \%$ \\
\hline 0.100 & 0.0050 & 1.00 & 0 & 0.0009 & 0.000010 & 0.77 & 1.175 & 0.009 & 0.002 & $34 \%$ & $-554 \%$ \\
\hline 4.600 & 0.42 & 1.27 & 0 & 0.0710 & 0.098 & 0.80 & 98.70 & 0.015 & 0.233 & $9 \%$ & $-49 \%$ \\
\hline 4.500 & 0.166 & 1.20 & 0 & 0.0930 & 0.082 & 0.80 & 39.01 & 0.021 & 0.494 & $13 \%$ & $-11 \%$ \\
\hline 4.400 & 0.0350 & 1.15 & 0 & 0.1560 & 0.044 & 0.79 & 8.225 & 0.035 & 1.257 & $10 \%$ & $-27 \%$ \\
\hline 4.300 & 0.0153 & 1.14 & 0 & 0.1810 & 0.025 & 0.78 & 3.596 & 0.042 & 1.634 & $6 \%$ & $-46 \%$ \\
\hline 4.300 & 0.0065 & 1.14 & 0 & 0.2000 & 0.0143 & 0.78 & 1.528 & 0.047 & 2.200 & $2 \%$ & $-43 \%$ \\
\hline 4.300 & 0.0031 & 1.14 & 0 & 0.2100 & 0.0075 & 0.78 & 0.729 & 0.049 & 2.419 & $0 \%$ & $-50 \%$ \\
\hline 4.400 & 0.0016 & 1.14 & 0 & 0.2200 & 0.0052 & 0.78 & 0.371 & 0.050 & 3.291 & $-1 \%$ & $-19 \%$ \\
\hline
\end{tabular}




\section{Distribution}

N. M. Askew, 773-A

N. E. Barnett, 707-F

S. E. Booth, 221-H

D. W. Braselman, 221-H

T. G. Campbell, 221-F

M. C. Chandler, 704-2H

D. L. Dolin, 704-2H

J. L. Dunning, 221-H

W. G. Dyer, 704-2H

O. M. Ebra-Lima, 707-F

R.E. Edwards, 704-2H (DOE)

J. S. Evans, 703-F

S. E. Federman, 704-2H

R. A. Frushour, 704-2H

C. R. Goergen, 221-H

A. P. Gouge, 735-11A

F. R. Graham, 773-A

J. H. Gray, 773-A

M.E. Hodges, 773-41 A

D. R. Johnson, 704-2H

D.G. Karraker, 773-A

J. C. Knight, 704-2H

J. R. Knight, 773-A

E. A. Kyser, 773-A

C. E. Pickett, 221-H

T. S. Rudisill, 773-A

T.M. Smith, 703-F (DOE)

M. C. Thompson, 773-A

G. J. Winkler, 703-F

C. R. Wolfe, 773-A 